\title{
The beginning of the Buntsandstein cycle (Early-Middle Triassic) in the Catalan Ranges, NE Spain: Sedimentary and palaeogeographic implications
}

\author{
Belén Galán-Abellán ${ }^{\text {a }}$, José López-Gómez ${ }^{\mathrm{b}, *}$, José F. Barrenechea ${ }^{\mathrm{c}, \mathrm{d}}$, Mariano Marzo ${ }^{\mathrm{e}}$, \\ Raúl De la Horra ${ }^{\mathrm{a}}$, Alfredo Arche ${ }^{\mathrm{b}}$ \\ a Departamento de Estratigrafía, Fac. Geología, Univ. Complutense de Madrid, C/José Antonio Nováis 2, 28040 Madrid, Spain \\ b Instituto de Geociencias, IGEO (CSIC-UCM), C/José Antonio Nováis 2, 28040 Madrid, Spain \\ c Departamento de Cristalografía y Mineralogía, Fac. Geología, Univ. Complutense de Madrid, Spain \\ ' Instituto de Geociencias, IGEO (CSIC-UCM), C/José Antonio Nováis 2, 28040 Madrid, Spain \\ e Departament d'Estratigrafía, Paleontología i Geosciències Marines, Facultat de Geología, Univ. Barcelona, 08028 Barcelona, Spain
}

The Early-Middle Triassic siliciclastic deposits of the Catalan Ranges, NE Spain, are dominated by aeolian sedi-ments indicating a predominance of arid climate during this time span, in sharp contrast with the coeval fluvial sediments found in the Castilian Branch of the Iberian Ranges, $300 \mathrm{~km}$ to the SW. The NE-SW-oriented Catalan Basin evolved during the Middle-Late Permian as the result of widespread exten-sion in the Iberian plate. This rift basin was bounded by the Pyrenees, Ebro and Montalbán-Oropesa highs. The Permian-Early Triassic-age sediments of the Catalan Basin were deposited in three isolated subbasins (Montseny, Garraf, Prades), separated by intrabasinal highs, but linked by transversal NW-SE oriented faults. The three subbasins show evidence of diachronic evolution with different subsidence rates and differences in their sedimentary records.

The Buntsandstein sedimentary cycle started in the late Early Triassic (Smithian-Spathian) in the central and southern domains (Garraf and Prades), with conglomerates of alluvial fan origin followed by fluvial and aeolian sandstones. Source area of the fluvial sediments was nearby Paleozoic highs to the north and west, in contrast with the far-away source areas of the fluvial sediments in the Iberian Ranges, to the SW. These fluvial systems were interacting with migrating aeolian dune fields located towards the S, which developed in the shadow areas behind the barriers formed by the Paleozoic highs. These highs were separating the subbasins under arid and semi-arid climate conditions. The dominating winds came from the east where the westernmost coast of the Tethys Sea was located, and periods of water run-off and fields of aeolian dunes development alternated. Some of the fluvial systems were probably evaporating as they were mixed into the interdune areas, never reaching the sea.

From the end of the Smithian to the Spathian, the Catalan Basin and neighbour peri-Tethys basins of the present-day southern France, Sardinia and Minorca islands constituted a geographical arch where arid and semi-arid con-ditions represented an extension of the prevailed arid and hyper-arid conditions in surrounding areas of the Variscan Belt. Harsh climatic conditions in this area prevented the life recovery in the aftermath of the Perm-ian-Triassic extinction event until the early Anisian, when more humid climate allowed for the colonisation of the area by plants, amphibians and reptiles. The boundary between desert areas and semi-arid and/or seasonal climate domains during the Smithian-Spathian in SW Europe can be precisely established in NE Iberia, between the Catalan-Ebro region and the Castilian Branch of the Iberian Ranges, to the SW.

Keywords: Catalan Ranges Aeolian facies Triassic climate Spathian Anisian

\section{Introduction}

The Early Triassic was marked by physical-chemical global variations related to the drastic palaeoenvironmental changes produced around the Permian-Triassic transition (e.g. Erwin, 1993, 2006; Martin and Macdougall, 1995; Benton, 2003). These perturbations resulted from related events, such us massive volcanism from the Siberian Traps and its consequent general geochemical anomalies, and widespread mass mortality episode. Protracted volcanic episodes and related oxygen-depleted conditions and high $\mathrm{CO}_{2}$ partial pressure during the Early Triassic may have been a trigger for the continuation of the global variations of the carbon cycle during the Early Triassic and the delay of 
the subsequent recovery during this time (Pruss and Bottjer, 2005; Chen et al., 2007; Payne and Krump, 2007; Sellwood and Valdes, 2007; Bottjer et al., 2008; Hermann et al., 2011; Kearsey et al., 2011; Retallack et al., 2011; Galán-Abellán et al., 2013).

The characteristics of this particular period of time, that even persisted until the early Anisian, are recorded both in marine and continental rocks, where recent studies have described climate variations (Kidder and Worsley, 2004; Galfetti et al., 2007; Schneebeli-Hermann, 2012; Sun et al., 2012), paleoceanographic changes (Atudorei and Baud, 1997; Brühwiler et al., 2009), abrupt changes in sedimentation (Smith, 1995; Arche and López-Gómez, 2005; Pruss et al., 2005; Woods, 2005) and pulses of productivity and related punctual biodiversity increase (Twitchett, 1999; Payne and Krump, 2007). In spite of these studies, descriptions of Early Triassic continental rocks are comparatively scarce when compared with those dealing with rocks of marine origin. There is even an important lack of information of well-dated correlations between the observed marine and continental variations (López-Gómez et al., 2012). Gaps in the sedimentary record and fossil content are the main causes for hindering studies of the continental units, a fact that impedes detailed correlations between nearby basins and the understanding of palaeogeographical reconstructions during the Early Triassic.

The Catalan Coastal Ranges, NE Spain, show exceptional outcrops of continental rocks of Early-Middle Triassic age. This area, constituted by the so-called Catalan Basin during the Mesozoic times, represented one of the key-areas in Pangea megacontinent during the Early Triassic to reconstruct more precisely the transition from arid and hyper-arid areas in SW Europe to more humid, seasonal ones to the south. During this time the Catalan Basin was located about $8^{\circ} \mathrm{N}$ paleolatitude (Dinarès-Turell et al., 2005), in the central-eastern part of Pangea, and represented the natural connection between Iberia and the central Europe, a crucial location for understanding the drastic palaeogeographical and palaeoclimate changes occurred southwards of Northern Pangea at the beginning of the Mesozoic era.

This work focuses on the central and southern parts of the Catalan Ranges where Early and Middle Triassic continental rocks crop out. These rocks represent the first sedimentary cycle of the Mesozoic and constitute the lower part of the Buntsandstein facies. In spite of the good preservation of these outcrops, few detailed works have been published before the 1950s. The main objective of this article is to demonstrate the change in climatic and sedimentological conditions in a relatively small area in NE Iberia based on a reinterpretation of the superb exposures of the Catalan Ranges an its correlation with similar sections in the Ebro Basin and the Iberian Ranges. The marine sections of the Late Permian-Early Triassic period are much better known than its continental counterparts and this article tries to help to fill this gap.

Data in this paper present a new sedimentological interpretation of the Early Triassic sediments of the Catalan Ranges, where aeolian deposits and palaeohighs controlled fluvial development and paleogeography of NE Iberia much more than previous works admitted, what mostly considered only aeolian reworking on dominating fluvial development (Marzo and Anadón, 1977; Marzo, 1980) and the absence of hyper-arid conditions in these sediments (Gómez-Gras, 1993; Arche et al., 2004).

\section{Geological setting}

At the end of the Permian and during the Early Triassic Iberia was located in the central-eastern side of Pangea as a small plate in the southernmost part of the ancient Laurasia megacontinent (Arche and López-Gómez, 1996; López-Gómez et al., 2002; De Vicente et al., 2009; Vargas et al., 2009). The Catalan Basin was located northeast of Iberia and started its development during the Middle-Late Permian as a result of widespread extension in the Iberian plate. This basin evolved as a NESW oriented rift basin with conjugate NW-SE fault systems and was separated from other neighbouring basins by the Girona, Lleida and
Montalbán-Oropesa highs. Paleogene topography generation by thrusting, erosion and isostatic subsidence resulted in a $1.2-1.9 \mathrm{~km}$ high mountain range by the end of compression during the Oligocene (Roca et al., 1999; Gaspar-Escribano et al., 2004). Present landscape configuration of the Catalan Ranges is the result of Neogene intense tectonic subsidence and consequent flexural uplift, surface erosion and up to $4.5 \mathrm{~km}$ of coeval sedimentation in some basins (López-Blanco et al., 2000; Gaspar-Escribano et al., 2001).

The Permian-Early Triassic sedimentary filling of the Catalan Basin was deposited into three isolated grabens separated by Paleozoic highs which were linked to transversal NW-SE oriented faults. The three subbasins, Prades, Garraf and Montseny from SW to NE, are labelled A, B and C, respectively in Fig. 1. These subbasins had different subsidence rates, did not have identical evolution and show different sedimentary record (Marzo, 1980; Calvet and Marzo, 1994). A pioneer work in these rocks was produced by Virgili (1958); a detailed sedimentological analyses were done by Marzo and Anadón (1977), Anadón et al. (1979), Marzo (1980, 1986), Marzo and Calvet (1985), Calvet and Marzo (1994), and López-Gómez et al. (2005); a palynological analysis can be found in Solé de Porta et al. (1987); a petrographical study in Gómez-Gras (1993) and magnetostratigraphy analysis in Dinarès-Turell et al. (2005); and a first attempt of correlation between Catalan subbasins, the Ebro and the Iberian basins was presented by Arche et al. (2004).

The Early Triassic sedimentary record is mostly represented in the Prades and Garraf sectors and is almost absent in the Montseny sector. It is of continental origin and was clearly controlled by episodic subsidence pulses with brief quiescent periods. The beginning of the Anisian was marked by an interruption in sedimentation with paleosoils development (Calvet and Marzo, 1994), probably represented in the three subbasins, just before a final short-lived but intense rifting episode that mainly affected the northern Montseny sector (Marzo, 1980). The later westwards transgression of the Tethys Sea in eastern Iberia (Muschelkalk facies) during the middle-late Anisian represented the end of the continental sedimentation of the Buntsandstein cycle (Calvet et al., 1990).

\section{Stratigraphy and sedimentology of the Early Triassic units}

\subsection{Stratigraphy}

The present study follows the nomenclature of the stratigraphical units defined by Marzo (1980) and Calvet and Marzo (1994) using some modifications for the lower units (Fig. 2). Based on stratigraphical analysis and comparisons with neighbouring Permian-Triassic basins of Iberia, the latter authors described three sedimentary cycles on the Paleozoic basement cropping out with different thickness in the Prades, Garraf and Montseny sectors. Modifications introduced in this work for the lower sedimentary cycle are mainly based on two criteria: the data obtained from the magnetostratigraphy study of the Riera de San Jaume Sequence (RSJS) (Dinarès-Turell et al., 2005), and the detailed sedimentological study of this work. This latter study allow us to differentiate fluvial from fluvial with aeolian reworking among the conglomeratic units that, when compared with well-dated units of neighbouring basins allow us to separate a Permian - from a Triassic sedimentary cycle.

The first cycle is represented by decimetre-scale conglomerate sequences of presumed Middle-Late Permian age, the Prades Lower Conglomerates unit (PLC) and its lateral equivalent, the Garraf Conglomerates unit (GLC). Due to sedimentological differences between the lower and upper part of this unit, it is here separated into GLC-1 and GLC-2. A regional unconformity separates this cycle from the Triassic sedimentation (second and third cycles) (Fig. 3). The second cycle represents the beginning of Triassic deposition and may reach more than 100-m-thick. From base to top, in the Prades sector $(A)$ it is constituted by the Prades Upper Conglomerates unit (PUC) and the Prades Lower Sandstones unit (PLS) or their lateral equivalent the Garraf 


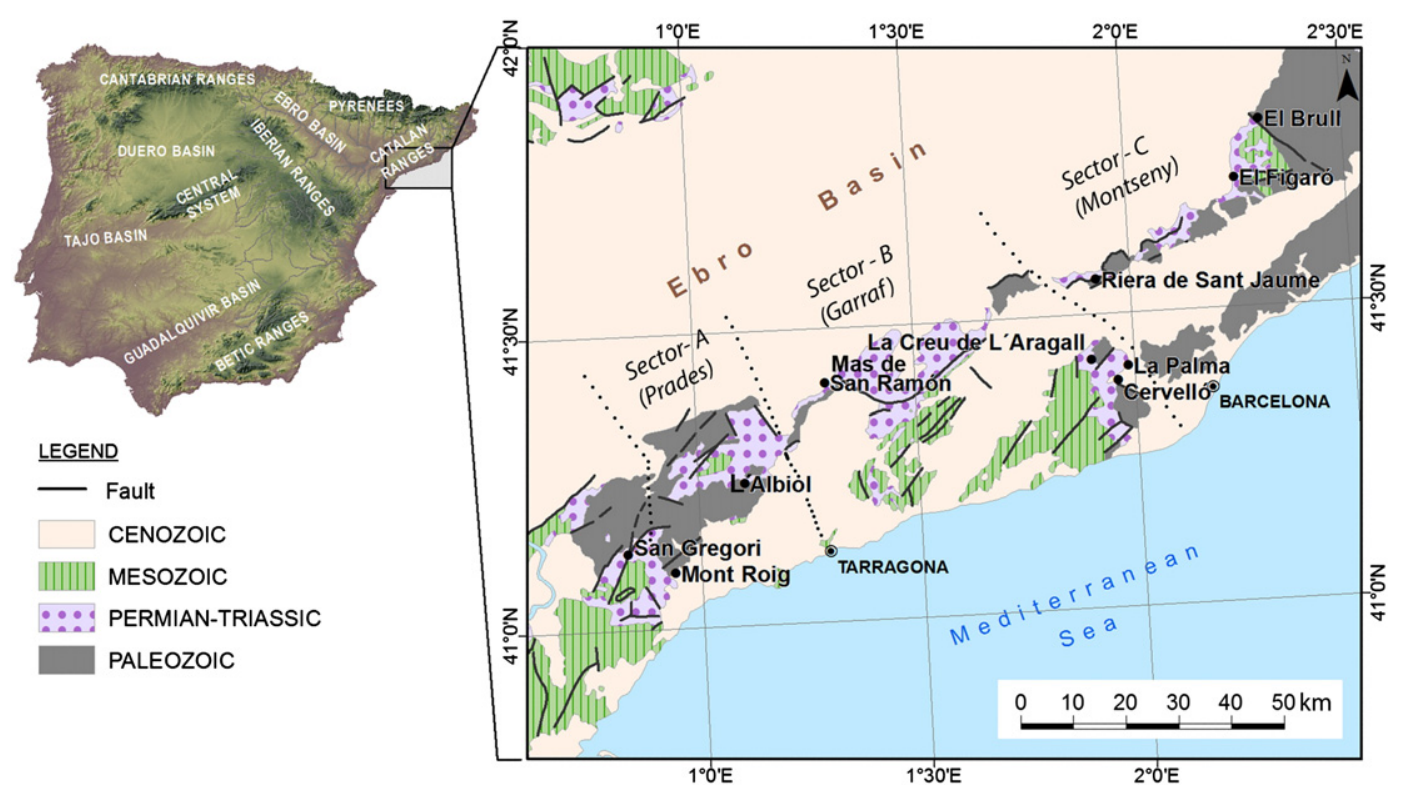

Fig. 1. Schematic geological map of the Catalan Ranges with indication of the study areas and field sections.

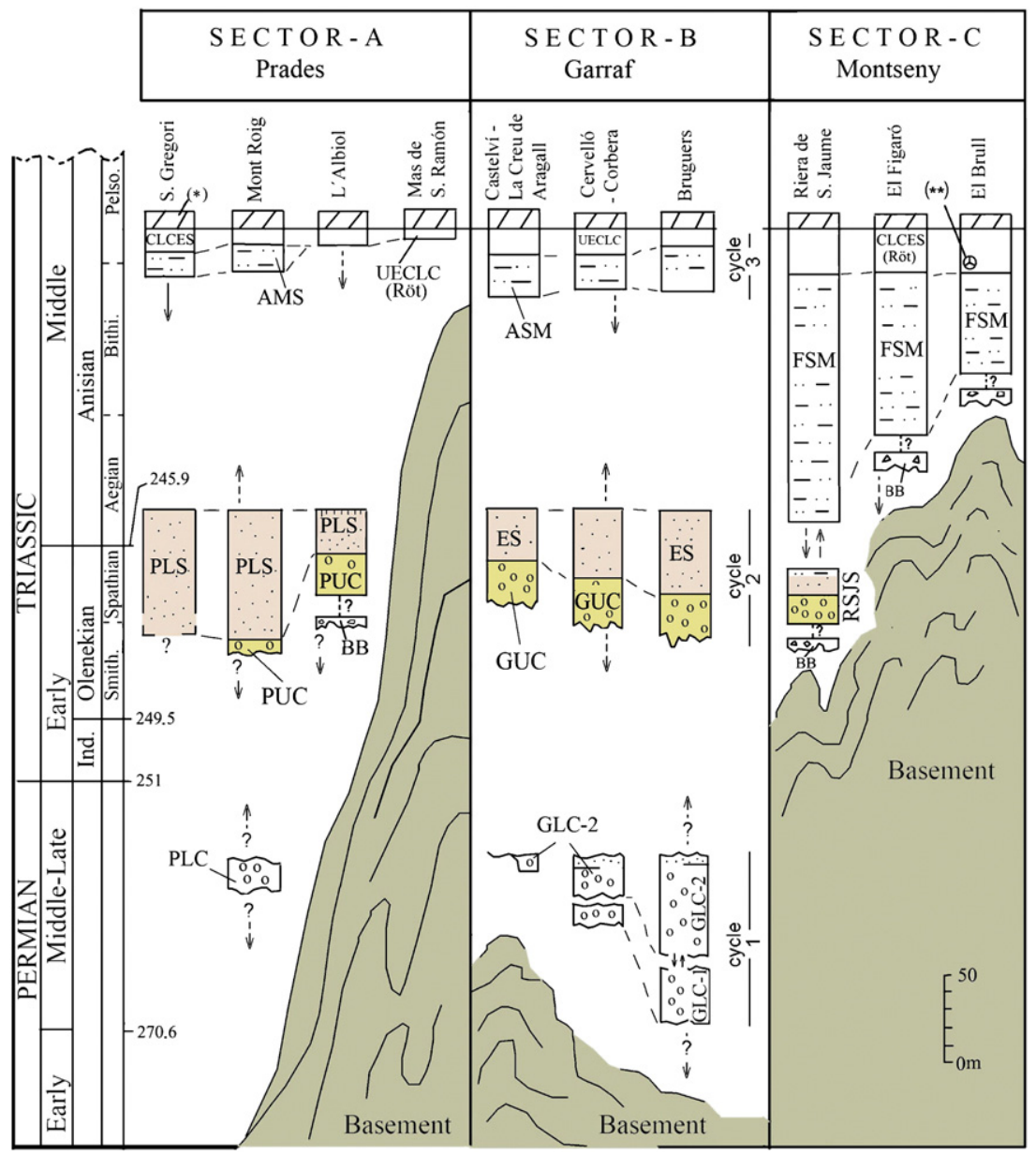

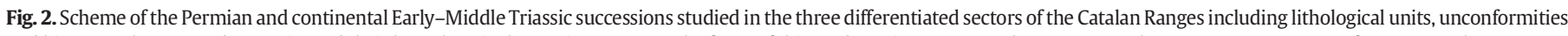

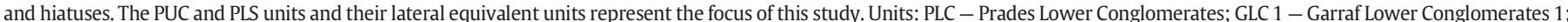

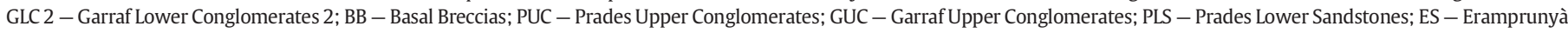

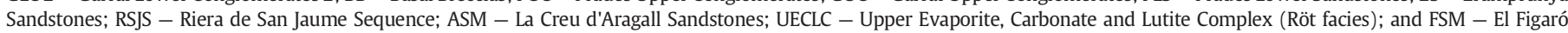
Sandstones and Mudstones. *Muschelkalk units. **Polen assemblage (Díez et al., 2012); see text for details. Stratigraphical nomenclature modified from Marzo (1980). 


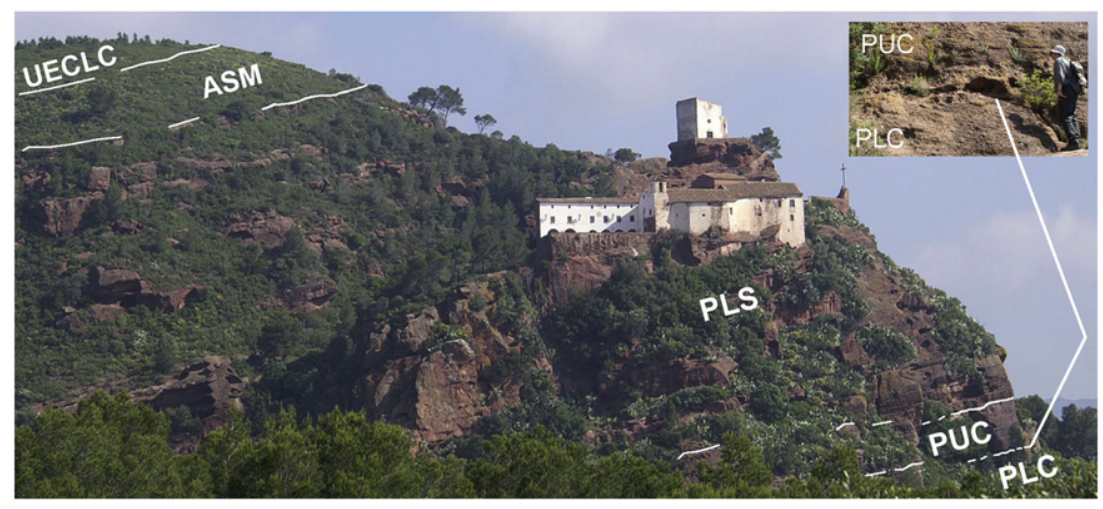

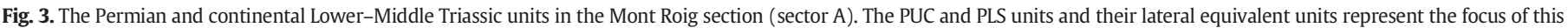
study. The unconformity between PLC and PUC (cycles 1 and 2 ) is shown in the small picture.

Upper Conglomerates unit (GUC) and the Eramprunyá Sandstones unit (ES) of the Garraf sector (B). The differentiation of the Garraf Conglomerates unit in two units changes a previous version of the same authors (Arche et al., 2004) that considered the whole Garraf Conglomerates unit into the Triassic. Therefore, the called Bruguer and Bellmunt Permian units (Calvet and Marzo, 1994) would be here the lateral and local equivalent to PLC.

This PUC-PLS succession and its lateral equivalent GUC-ES succession of the Garraf sector (B) are broadly equivalent to the Riera de San Jaume Sequence (RSJS) of the western area of the Montseny sector (C) (Fig. 2), which is resting on a local breccias (BB) that could be of Permian or Triassic age. Another clear regional sedimentary unconformity separates the basal Triassic cycle from the third one, which is represented from base to top by the Aragall Sandstones and Mudstones unit (ASM) or its lateral equivalent the El Figaró Sandstones and Mudstones unit (FSM), and the Upper Evaporite, Carbonate and Lutite Complex unit (UECLC) or Röt facies. This study will focus on the second cycle represented by units PUC, PLS and lateral equivalents (Figs. 2, 3).

\subsection{Sedimentology: facies and architectural elements}

For the study of the sedimentary analysis, a total of five complete sections have been studied in the three sectors (Fig. 4). These sections are representative of the different sectors: sector A is represented by San Gregori, Mont Roig and L'Albiol sections, while Cervelló and Riera de St. Jaume represent sectors B and C respectively. Sections vary in thickness depending on the sector. Maximum thickness is about $100 \mathrm{~m}$ and belongs to Mont Roig section, central part of sector A, while Riera St. Jaume section in sector C, which is about $30 \mathrm{~m}$ in thickness, shows the minimum thickness. Eastwards of sector $C$ the sedimentary record pinch out against the Paleozoic basement (Fig. 2).

In the studied units the two main lithologies are conglomerates and sandstones that were described and interpreted in detail by Marzo (1986). This latter author was the first describing the sediments of aeolian origin in the Triassic of the Catalan Ranges based on previous papers of coeval sediments of Central Europe (e.g. Clemmensen, 1978; Mader, 1981). Conglomerates represent the dominant lithology of the PUC unit. The principal lithology of the clasts is quartz, with quartzites and lidites as minor components. Sandy matrix may be locally abundant. Clasts are subangular to subrounded with 5-9 cm mean size. Red lutites appear as accessory lithology.

Sandstones mainly appear in PLS unit and show red colour and fine to medium size grains. Clay matrix content is less than 5\%. Rock fragments are rare and consist of polycrystalline quartz grains and schists fragments. Altered biotite also appears as accessory component and isolated quartz clasts may occur aligned along a surface or dispersed into the sandstones. Quartz grains are subangular to subrounded and 85$95 \%$ are of igneous origin. A lamprophyric sub-vertical dyke swarm complex described from Aiguablava area (Ubide et al., 2010) some tens of kilometres northwards of the study area, may provide information about this igneous origin.

The alluvial sedimentary characteristics of the PUC and PLS units are here described based on the differentiation of facies and facies associations, and then grouped to form architectural elements following Miall's nomenclature $(1992,1996)$. The nomenclature of the authors of this work is applied in the case of the aeolian sediments. The code of the facies consists of a prefix for rock type and a suffix for dominant internal structure. The sedimentary environments will be based on the analysis and interpretation of the different architectural bodies.

\subsubsection{Fluvial sediments}

Sediments of fluvial origin are common in both PUC and PLS units, although their presence clearly increase towards the $\mathrm{E}$ of the study area, in B and C sectors. A total of 13 facies have been differentiated (Fig. 5). These facies combine lithologies with different sedimentary and/or organic structures.

3.2.1.1. Facies description and interpretation. There are 5 fluvial facies related with conglomerates: Gt, Gp, Gmp, Gmt, Gms (Figs. 5, 6A-C). They are described and interpreted as follows:

Facies Gp: Quartz conglomerates with planar cross-stratification. They are clast-supported and show pink to white colour. Clasts are rounded to subrounded with mean size of $7 \mathrm{~cm}$. They occur as sets ranging in thickness from 20 to $45 \mathrm{~cm}$ that may constitute cosets of two-three sets reaching at least $1.5 \mathrm{~m}$ in total thickness (Fig. 6B). This facies is interpreted as two-dimensional gravel dune.

Facies Gt: Quartz conglomerates with trough cross-stratification. They are clast-supported and show pink to white colour. Clasts are rounded to subrounded with mean size of $6 \mathrm{~cm}$. Very thin lenses of sandstones commonly are present. They occur as sets ranging in thickness from 20 to $55 \mathrm{~cm}$. It frequently appears alternating with facies Gp (Fig. 6B). This facies is interpreted as three dimensional gravel dunes.

Facies Gmp: Quartz conglomerates with planar cross-stratification. They are matrix-supported and show pink to white colour. Clasts are rounded and may reach $4 \mathrm{~cm}$. Matrix is composed of medium to coarse sand with pink colour. They occur as sets ranging in thickness from 20 to $35 \mathrm{~cm}$ that may constitute cosets of two or more sets reaching at least $1.2 \mathrm{~m}$ in total thickness (Fig. 6B). This facies is interpreted as two dimensional dunes of sandstones and gravels. Facies Gmt: Quartz conglomerates with trough cross-stratification. They are matrix-supported and show pink to white colour. Clasts may reach $6 \mathrm{~cm}$. They are mainly rounded although subrounded clasts are also present. Matrix is composed of medium to coarse 


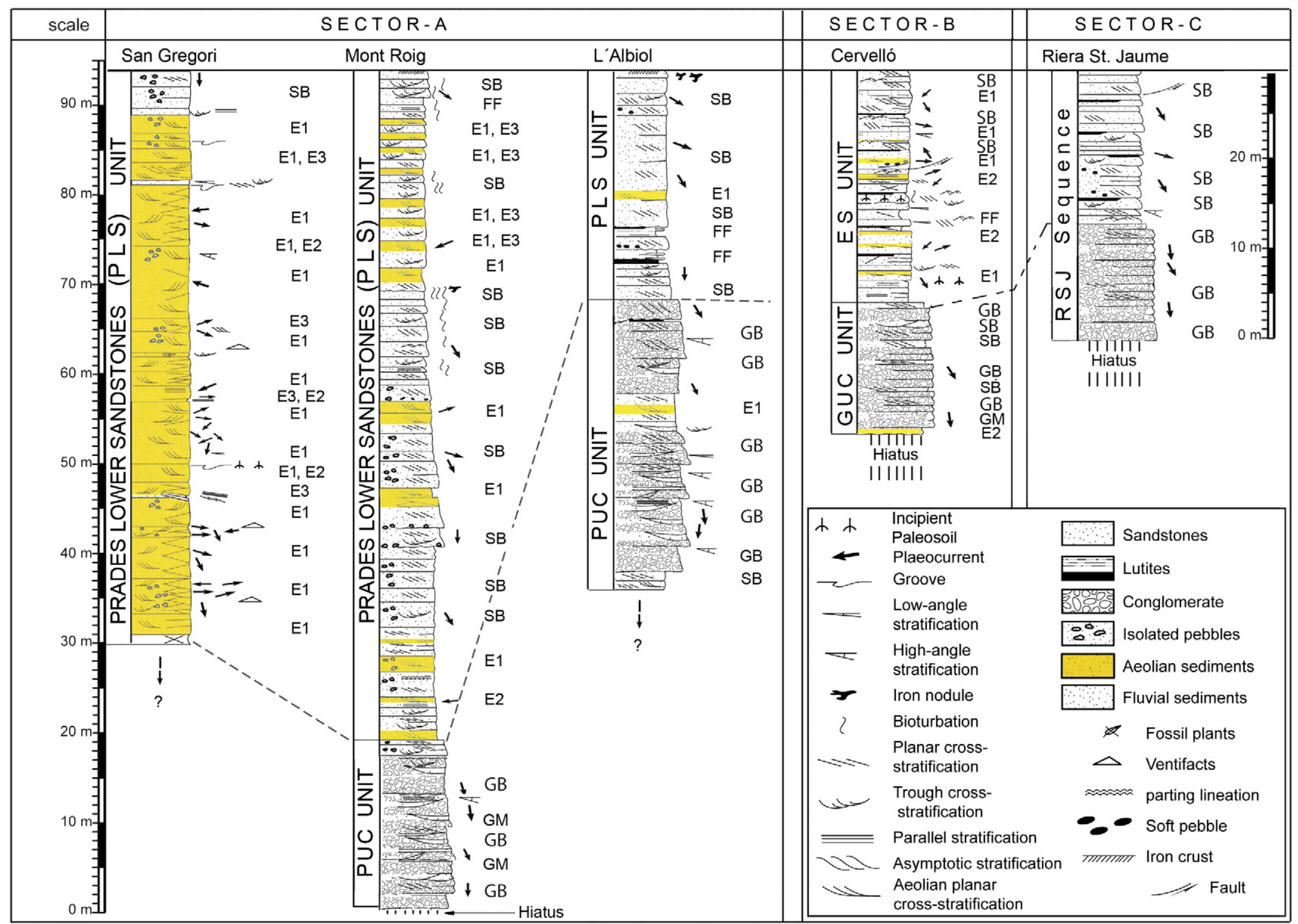

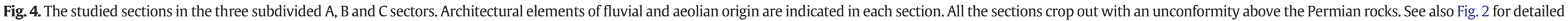
stratigraphical location of the units. 


\begin{tabular}{|c|c|c|c|}
\hline $\begin{array}{l}\text { Facies } \\
\text { code }\end{array}$ & Description & Location & Interpretation \\
\hline Gp & $\begin{array}{l}\text { Clast-supported pink to white quartz } \\
\text { conglomerates with planar cross-stratification. }\end{array}$ & $\begin{array}{l}\text { Proximal } \\
\text { to medium } \\
\text { areas }\end{array}$ & Two-dimensional gravel dunes \\
\hline Gt & $\begin{array}{l}\text { Clast-supported pink to white quartz } \\
\text { conglomerates with trough cross-stratification. }\end{array}$ & $\begin{array}{l}\text { Proximal } \\
\text { to medium } \\
\text { areas }\end{array}$ & Three-dimensional gravel dunes \\
\hline Gmp & $\begin{array}{l}\text { Matrix-supported pink to white quartz } \\
\text { conglomerates with planar cross-stratification }\end{array}$ & $\begin{array}{l}\text { Medium to } \\
\text { distal areas }\end{array}$ & $\begin{array}{l}\text { Two-dimensional dunes of sandstones } \\
\text { and gravels }\end{array}$ \\
\hline Gmt & $\begin{array}{l}\text { Matrix-supported pink to white quartz } \\
\text { conglomerates with trough cross-stratification }\end{array}$ & $\begin{array}{l}\text { Medium to } \\
\text { distal areas }\end{array}$ & $\begin{array}{l}\text { Three-dimensional dunes of sandstones } \\
\text { and gravels }\end{array}$ \\
\hline Gms & $\begin{array}{l}\text { Massive and crude flat-bedding white angular/ } \\
\text { subrounded clasts. Low sandy matrix proportion } \\
\text { or even clast supported }\end{array}$ & $\begin{array}{l}\text { Proximal } \\
\text { areas }\end{array}$ & $\begin{array}{l}\text { Low-strength flow deposited from } \\
\text { viscous, laminar or turbulent flows }\end{array}$ \\
\hline St & $\begin{array}{l}\text { Fine to coarse red-pink sandstones with } \\
\text { trough cross-stratification and occasional } \\
\text { reactivation surfaces. Clay chips and isolated } \\
\text { quartz clasts can appear. They normally show } \\
\text { fining-upwards tendency }\end{array}$ & $\begin{array}{l}\text { Medium } \\
\text { areas }\end{array}$ & $\begin{array}{l}\text { Dune of sandstone with sinuous } \\
\text { crest (3D) of linguoid type }\end{array}$ \\
\hline Sp & $\begin{array}{l}\text { Fine to medium red-pink sandstones with planar } \\
\text { cross-stratification and isolated quartz clasts. They } \\
\text { normally show fining-upwards tendency }\end{array}$ & $\begin{array}{l}\text { Medium } \\
\text { areas }\end{array}$ & $\begin{array}{l}\text { Dunes of sandstones with straight } \\
\text { crest (2D) of linguoid type. }\end{array}$ \\
\hline Sh & $\begin{array}{l}\text { Fine to medium red-pink sandstones with parallel } \\
\text { lamination and plane base. Parting-lineation is } \\
\text { common }\end{array}$ & $\begin{array}{l}\text { Medium to } \\
\text { distal }\end{array}$ & Upper-stage phase beds movements \\
\hline $\mathrm{Sr}$ & $\begin{array}{l}\text { Fine to medium red-pink sandstones with current } \\
\text { ripples }\end{array}$ & $\begin{array}{l}\text { Medium to } \\
\text { distal areas }\end{array}$ & Low-stage phase beds movements \\
\hline Sbp & $\begin{array}{l}\text { Fine red-orange sandstones with vertical } \\
\text { bioturbation and isolated plant remains }\end{array}$ & $\begin{array}{l}\text { Medium to } \\
\text { distal areas }\end{array}$ & Near channel overflowing \\
\hline $\mathrm{Fr}$ & $\begin{array}{l}\text { Fine grain sandstone or mudstone, masive with } \\
\text { small rootlets }\end{array}$ & $\begin{array}{l}\text { Distal } \\
\text { areas }\end{array}$ & $\begin{array}{l}\text { Abandoned channel or near channel } \\
\text { deposits }\end{array}$ \\
\hline $\mathbf{F b}$ & $\begin{array}{l}\text { Red dark mudstones or fine-grain pink sandstones } \\
\text { with punctually mud-cracks and paleosoils } \\
\text { development }\end{array}$ & $\begin{array}{l}\text { Distal } \\
\text { areas }\end{array}$ & $\begin{array}{l}\text { Abandoned channel or near channel } \\
\text { deposits }\end{array}$ \\
\hline FI & $\begin{array}{l}\text { Centimetre beds of fine red (sometimes green) } \\
\text { sandstones with current ripples into dark } \\
\text { red mudstones }\end{array}$ & $\begin{array}{l}\text { Distal } \\
\text { areas }\end{array}$ & Near channel overflowing \\
\hline
\end{tabular}

Fig. 5. Description and interpretation of the PUC and PLS unit fluvial facies. Nomenclature based on Miall (1996).
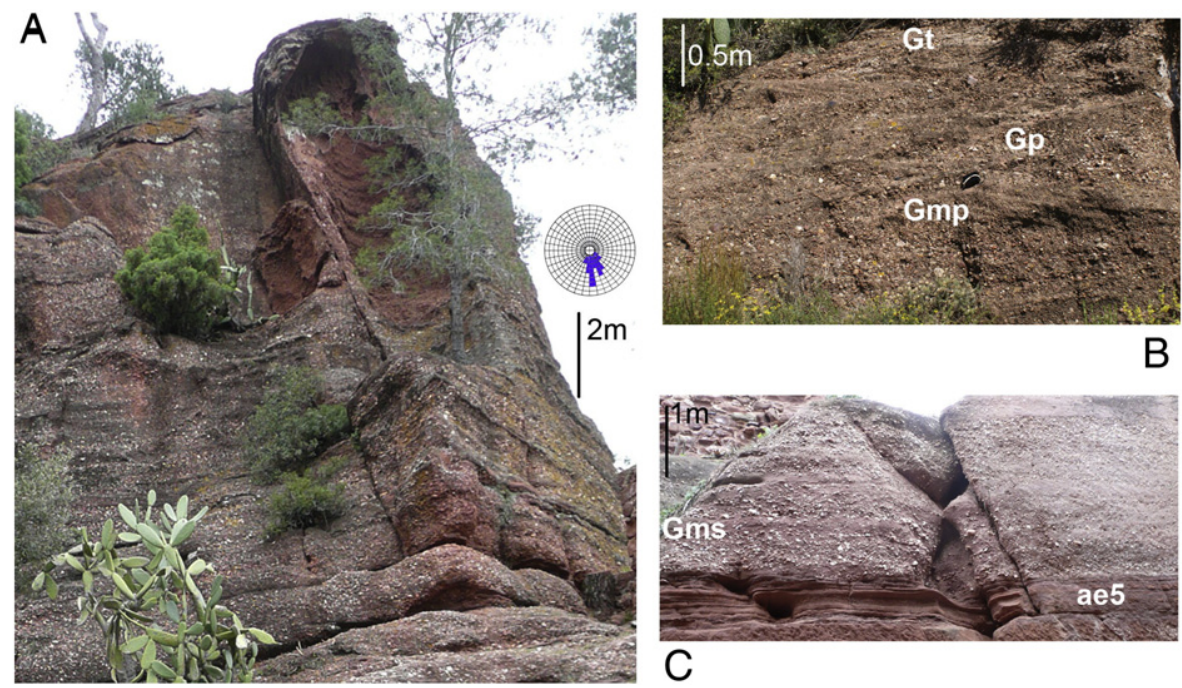

B

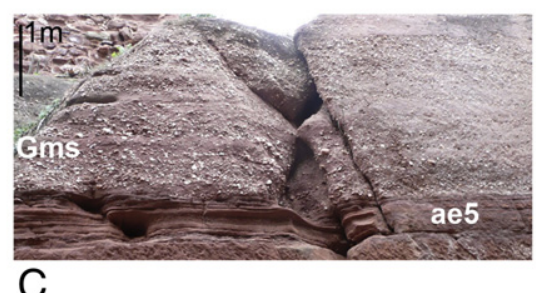

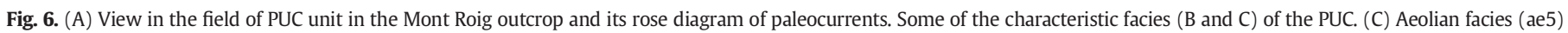
intercalated with fluvial facies (Gms) in Cervelló section. 

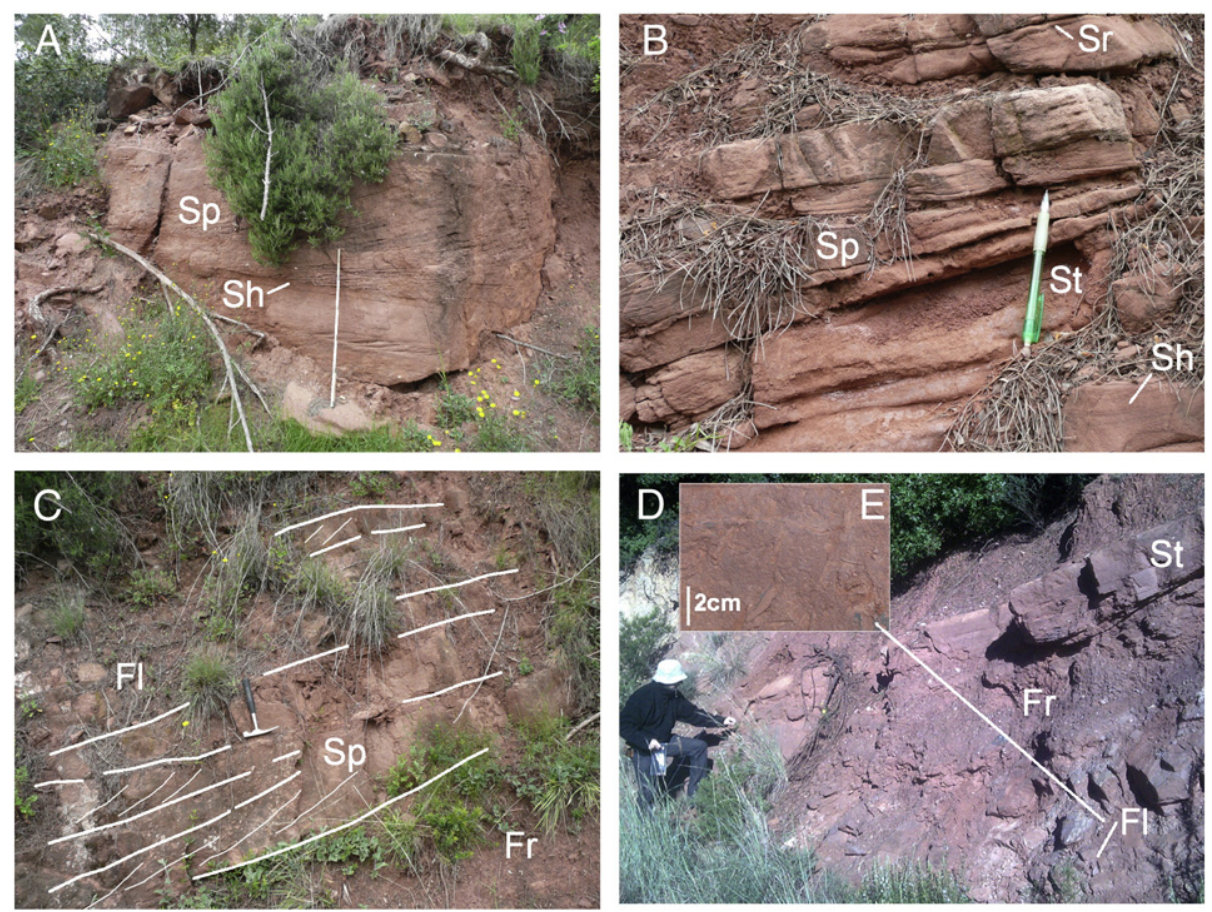

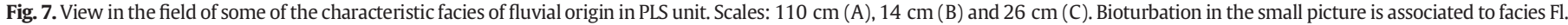

sand (rare angular grains up to $2 \mathrm{~mm}$ in diameter) with pink colour. They occur as sets ranging in thickness from 25 to $40 \mathrm{~cm}$ that may constitute cosets of two or more sets reaching at least $1.4 \mathrm{~m}$ in total thickness. This facies is interpreted as three dimensional dunes of sandstones and gravels.

Gms: Conglomerates with massive and crude flat-bedding white angular and subrounded clasts of quartz. They show pink colour and low sandy matrix proportion or even they are clast supported. Matrix is composed by red to pink medium to coarse sandstones. They occur as sets ranging in thickness from 30 to $60 \mathrm{~cm}$ that locally may alternate with aeolian facies (Fig. 6C). This facies is interpreted as low-strength flow deposited from viscous, laminar or turbulent flows.
There are 5 fluvial facies related with sandstones: Sp, St, Sh, Sr, Sbp (Figs. 5, 7A-D). They are described and interpreted as follow:

Facies St: Sandstones with trough cross-stratification. They are fine to coarse with red-pink colour and normally show finning-upward tendency. Clay chips, small isolated quartz clasts and occasional reactivation surfaces can appear. They normally constitute sets less than $30 \mathrm{~cm}$ (Fig. 7B, D). This facies is interpreted as migration of sandstone dune with sinuous crest of linguoid type in shallow water. Facies Sp: Sandstones with planar cross-stratification. They are fine to coarse with red-pink colour and normally show finning-upward tendency. Small reactivation surfaces can appear. They normally constitute sets less than $25 \mathrm{~cm}$ (Fig. 7A-C). This facies is interpreted

\begin{tabular}{|c|c|c|c|c|}
\hline \multicolumn{2}{|c|}{ Architectural elements } & Code & $\begin{array}{l}\text { Main facies and } \\
\text { associated facies }\end{array}$ & General morphology \\
\hline \multirow{5}{*}{$\begin{array}{l}\bar{\pi} \\
\overline{2} \\
= \\
\bar{I}\end{array}$} & $\begin{array}{l}\text { Megariples (mesoforms) of } \\
\text { sandstones with erosive or } \\
\text { planar base and basal lag }\end{array}$ & SB & $\begin{array}{l}\text { St, Sp } \\
\text { Sh, Sr, ae4 }\end{array}$ & $\begin{array}{l}\text { Sheet forms that occur as } \\
\text { channel-fill }\end{array}$ \\
\hline & $\begin{array}{l}\text { Chanel-fill complex of sand- } \\
\text { stones with defined margins } \\
\text { and internal erosive surfaces }\end{array}$ & $\mathrm{CH}$ & $\begin{array}{l}\mathrm{Sp}, \mathrm{St} \\
\mathrm{Sh}, \mathrm{Sr}\end{array}$ & $\left.\right|_{\text {Concave-up erosional base }} ^{2.1 \mathrm{~m}}$ \\
\hline & $\begin{array}{l}\text { Gravel bars and bedforms. } \\
\text { Mesoforms are normally } \\
\text { amalgamated into macroforms }\end{array}$ & GB & $\begin{array}{l}\mathrm{Gp}, \mathrm{Gmp}, \mathrm{Gmt}, \mathrm{Gt} \\
S p\end{array}$ & $\begin{array}{l}\text { Erosive base and isolated } \\
\text { Sand wedges }\end{array}$ \\
\hline & $\begin{array}{l}\text { Unconfined or semi-confined } \\
\text { clast sedimentation. Beds show } \\
\text { massive-crude stratification and } \\
\text { sets may reach } 1 \mathrm{~m} \text { in thickness }\end{array}$ & GM & $\begin{array}{l}\text { Gms } \\
\text { Gmp, St }\end{array}$ & 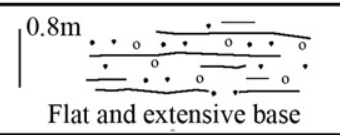 \\
\hline & $\begin{array}{l}\text { Floodplain fines. They may } \\
\text { reach } 10 \text { s of } m \text { thick. Sand- } \\
\text { stone bodies may appear inter- } \\
\text { calated. }\end{array}$ & $\mathrm{FF}$ & $\begin{array}{l}\mathrm{Fr} \\
F b, F l, S b p\end{array}$ & 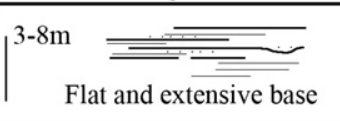 \\
\hline
\end{tabular}

Fig. 8. Fluvial architectural elements and their main characteristics defined for PUC and PLS units. 
as migration of small-scale two dimensional dune of sandstone in shallow water.

Facies Sh: Sandstones with parallel lamination. They are fine to medium with red-pink colour and normally show plane base and parting lineation. They constitute individual sets less than $25 \mathrm{~cm}$ (Fig. 7A, B). This facies is interpreted as upper-stage phase beds' movement (critical flow when associated to parting lineation).

Facies Sr: Sandstones of fine to medium grain. They have pink colour and asymmetric ripples (Fig. 7B). This facies is interpreted as sedimentation during low-stage phase beds' movements.

Facies Sbp: Sandstones with fine grain and red-orange colour. They show irregular lamination with sporadic bioturbation and very scarce small plant remains. This facies is interpreted as near channel overflowing.

There are 3 facies related with mudstones and very fine grain sandstones: Fr, Fb, Fl (Figs. 5, 7). They are described and interpreted as follow:

Facies Fr: Mudstone or fine grained sandstone with red dark colour. It is massive and shows vertically oriented root cast (Fig. 7C, D). This facies is interpreted as abandoned channel or near channel deposits. Facies $F b$ : Mudstone or fine grained sandstone, massive or lightly laminated, with red dark colour. It shows mud-cracks and occasionally small paleosoils development. This facies is interpreted as abandoned channel or near channel deposits.

Facies Fl: Fine red (sometimes green) sandstones with asymmetric ripples constituting centimetre beds into dark red massive mudstones. Bioturbation can appear (Fig. 7C-E). This facies is interpreted as near channel overflowing.
3.2.1.2. Facies associations and architectural elements. The 13 differentiated facies in the fluvial sediments tend to be organized into elementary facies associations. These associations are used to define 5 architectural elements (Fig. 8). Each of these elements is defined by a code and shows a particular morphology that is constituted by main and associated facies, and represents the base for the interpretation of fluvial environments and palaeogeography. They are located into each of the studied sections (Fig. 4). The 5 architectural elements include:

Architectural element SB: This element is constituted by St and Sp main facies, with $\mathrm{Sh}, \mathrm{Sr}$ and ae4 as associated facies. It represents sandstone megaripples with erosive or planar base and shows sheet forms that occur as channel-fill.

Architectural element $\mathrm{CH}$ : This element is constituted by $\mathrm{Sp}$ and $\mathrm{St}$ main facies, with $\mathrm{Sh}$ and $\mathrm{Sr}$ as associated facies. It represents channel-fill complex of sandstones with defined margins and shows concave-up erosional base and internal erosive surfaces.

Architectural element GB: This element is constituted by Gp, Gmp, Gmt and Gt main facies, with Sp as associated facies. It represents gravel bars and bedforms that may be amalgamated into macroforms and shows erosive base and isolated sand wedges. Architectural element GM: This element is constituted by Gms main facies, with Gmp and St associated facies. It represents unconfined or semi-confined clast sedimentation and shows flat and extensive base.

Architectural element FF: This element is constituted by Fr main facies, with $\mathrm{Fb}, \mathrm{Fl}$ and $\mathrm{Sbp}$ as associated facies. It represents floodplain fines with intercalated thin bodies of fine sandstones showing flat and extensive base.

\begin{tabular}{|c|c|c|c|}
\hline $\begin{array}{l}\text { Facies } \\
\text { code }\end{array}$ & Description & Location & Interpretation \\
\hline ae1 & $\begin{array}{l}\text { Pale yellow, medium-grained, well-rounded } \\
\text { and sub-angular quartz grains. They constitute } \\
\text { sets with cross-bedded sandstones up to } 2.7 \mathrm{~m} \\
\text { in thickness. }\end{array}$ & $\begin{array}{l}\text { Proximal } \\
\text { to medium } \\
\text { areas }\end{array}$ & $\begin{array}{l}\text { Migration of aeolian } \\
\text { dunes by avalanching } \\
\text { in the lee slope. }\end{array}$ \\
\hline ae2 & $\begin{array}{l}\text { Laterally continuous orange to light brown } \\
\text { units of fine-grained sandstone laminations } \\
\text { less than } 3 \mathrm{~mm} \text { in thickness. }\end{array}$ & $\begin{array}{l}\text { Proximal } \\
\text { to medium } \\
\text { areas }\end{array}$ & $\begin{array}{l}\text { Aeolian grainfall strata } \\
\text { related to saltation of } \\
\text { sand-size particles over } \\
\text { the brink of a dune }\end{array}$ \\
\hline ae3 & $\begin{array}{l}\text { Pale yellow, fine to medium-grained, well- } \\
\text { rounded quartz grains. Sub-angular to well- } \\
\text { rounded quartz appear. They constitute sets } \\
\text { with planar or trough cross-statification that } \\
\text { may reach more than } 1 \mathrm{~m} \text { with inversely } \\
\text { graded sand tongues up to } 15 \mathrm{~mm} \text { thick. }\end{array}$ & $\begin{array}{l}\text { Medium } \\
\text { to distal } \\
\text { areas }\end{array}$ & $\begin{array}{l}\text { Aeolian grain flow strata } \\
\text { related to avalanching in } \\
\text { the dune lee slope during } \\
\text { the dune migration. }\end{array}$ \\
\hline ae4 & $\begin{array}{l}\text { Yellow-white to salmon-pink, fine-grained } \\
\text { well-sorted sandstone with sub-horizontal } \\
\text { laminations up to } 2 \mathrm{~mm} \text { thick }\end{array}$ & $\begin{array}{l}\text { Distal } \\
\text { areas }\end{array}$ & $\begin{array}{l}\text { Wind ripple-laminated/ } \\
\text { translatent strata } \\
\text { sandstone due to } \\
\text { migration of aeolian } \\
\text { wind ripples }\end{array}$ \\
\hline ae5 & $\begin{array}{l}\text { Salmon-pink, fine-grained, well-sorted } \\
\text { horizontally laminated sandstone. } \\
\text { Laminations from } 10 \text { to } 20 \mathrm{~mm} \text { thick. } \\
\text { Bioturbation is very scarce. }\end{array}$ & $\begin{array}{l}\text { Distal } \\
\text { areas }\end{array}$ & $\begin{array}{l}\text { Horizontally laminated } \\
\text { (flat-bedded) sandstone } \\
\text { originated during stages } \\
\text { with high wind velocity } \\
\text { and restricted sediment } \\
\text { availability. }\end{array}$ \\
\hline ae6 & $\begin{array}{l}\text { Orange to light brown, fine-grained sandstone } \\
\text { without internal structure. Motting and scarce } \\
\text { bioturbation (rootlets) appear. }\end{array}$ & $\begin{array}{l}\text { Medium } \\
\text { to distal } \\
\text { areas }\end{array}$ & $\begin{array}{l}\text { Remnant of aeolian } \\
\text { sediments related to } \\
\text { alluvial overflowing } \\
\text { areas }\end{array}$ \\
\hline
\end{tabular}

Fig. 9. Description and interpretation of the six defined facies in the aeolian sediments of PUC and PLS units. 


\subsubsection{Aeolian sediments}

Sediments of aeolian origin represent almost half of the total of PLS unit, however they are very scarce in PUC unit (Fig. 4). The extent of these sediments in PLS unit is clearly related to the location in the three differentiated sectors. In the western part of sector A aeolian sediments represent almost the total thickness of San Gregori section, however this percentage gradually decreases eastwards, disappearing in the Riera de St. Jaume section, in sector C.

3.2.2.1. Facies description and interpretation. A total of 6 aeolian main facies (Figs. 9, 10) and 10 associated or secondary facies (Fig. 11) have been differentiated. Main facies includes:
Facies ae1: Sandstones of medium-grained and well-rounded to subangular quartz gains. It is of pale yellow colour and constitutes beds with cross-stratification that may reach up to $2.7 \mathrm{~m}$ in thickness and more than $10 \mathrm{~m}$ of lateral extension (Fig. 10a). This facies is interpreted as migration of aeolian dunes by avalanching in the lee slope.

Facies ae2: Sandstones of fine-grained and well-rounded quartz grains. It is of orange light brown colour and constituted by laterally continuous fine laminations less than $3 \mathrm{~mm}$ in thickness (Fig. 10b). This facies is interpreted as grain fall strata related to saltation of sand-size particles over the brink of a dune.
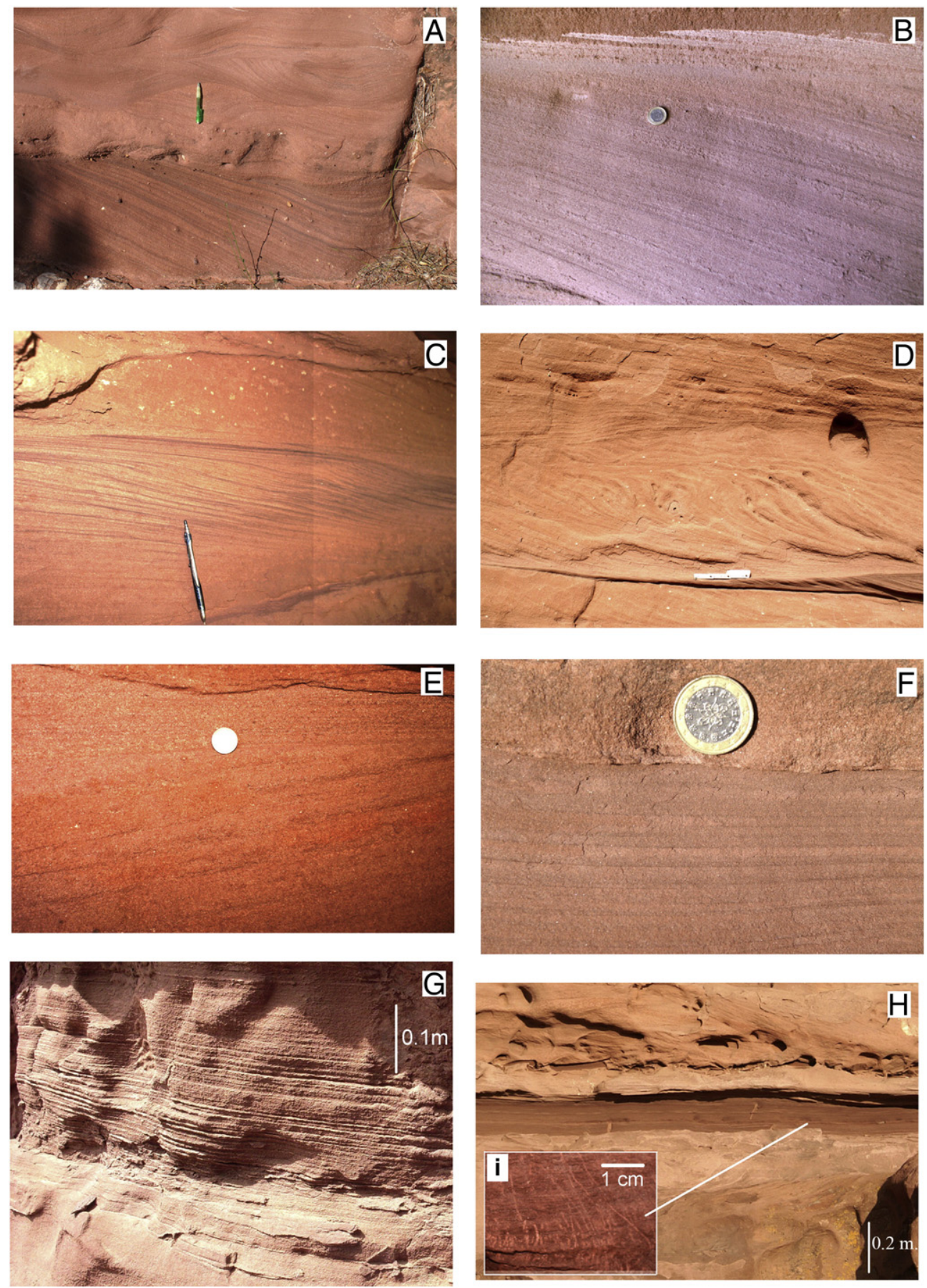

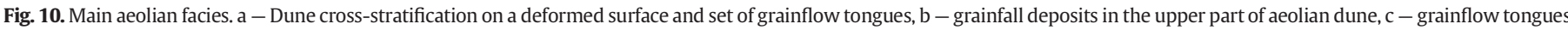

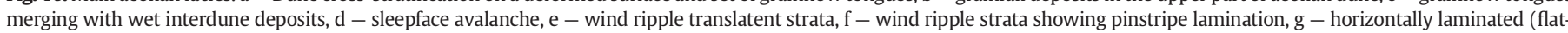
bedded) sandstone, $\mathrm{h}$ - dune cross-stratification on a erosive surface and wet interdune strata with bioturbation (i). 


\begin{tabular}{|l|l|}
\hline $\begin{array}{l}\text { Facies } \\
\text { code }\end{array}$ & Description of associated facies \\
\hline rs & Reactivation surfaces \\
ss & Small erosive grooves \\
ad & Small avalanching deposits \\
ds & Small-scale liquefaction structures \\
df & Deflaction surfaces with angular clasts \\
vs & Ventifacts \\
dc & Desiccation crack \\
pl & Pinstripe lamination \\
ssrg & Steep surface with well-sorted grains \\
wl & Wavy laminae \\
\hline
\end{tabular}

Fig. 11. Ten defined associated or secondary aeolian facies. They are associated to main facies and complete the description of the aeolian architectural elements.

Facies ae3: Sandstones of fine to medium-grained and sub-angular to well-rounded quartz grains. It is of pale yellow colour and constituted by sets with planar or trough cross-stratification that may reach $1 \mathrm{~m}$ in thickness. It shows inversely graded sand tongues up to $15 \mathrm{~mm}$ thick (Fig. 10c). This facies is interpreted as grain flow strata related to avalanching in the dune lee slope during the dune migration.

Facies ae4: Sandstones of fine-grained and well-rounded quartz grains. It is of yellow-white to salmon-pink colour and shows irregular or sub-horizontal laminations up to $2 \mathrm{~mm}$ thick (Fig. 10e). This facies is interpreted as wind ripple-laminated/translatent strata related to migration of wind ripples.

Facies ae5: Sandstones of fine-grained and well-rounded quartz grains. It is of salmon-pink colour and it is constituted by laminations 10-20 mm thick (Fig. 10g). Bioturbation may punctually appear. This facies is interpreted as flat-bedded sandstone related to stages with high wind velocity and restricted sediment availability.

Facies ae6: Sandstones of fine-grained quartz grains. It is orange to light brown colour and without clear internal structure. It shows mottling and scarce bioturbation (rootlets) (Fig. 10h, i). This facies is interpreted as remnant of aeolian sediments related to alluvial overflowing areas.

There are 10 differentiated facies that may appear associated to the 6 main facies described above. These facies are denominated secondary or associated and are mostly represented by sedimentary structures in sandstones. Each of these facies is denominated by a code (Fig. 11). These associated facies are: reactivation surfaces (rs), small erosive grooves (ss), small avalanching deposits (ad), small-scale liquefaction structures (ds), deflaction surfaces with angular clasts (df), ventifacts (vs), sandstones with desiccation cracks (dc), pinstripe lamination (pl), steep surfaces with well-sorted grains (ssrg) and wavy laminae (wl).

3.2.2.2. Facies associations and architectural elements. The differentiated main and associated or secondary facies in the aeolian sediments tend to be organized into elementary facies associations. These associations are used to define 3 architectural elements (Figs. 12, 13A-F). Each of these elements is defined by a code and shows a particular morphology and represents the base for the interpretation of aeolian environments and palaeogeography. They are located into each of the studied sections (Fig. 4). The 3 architectural elements are:

Architectural element E1 (Dune): This element is constituted by ae1, ae2, ae3 and ae4 main facies, with ad, vs, ds, rs, ssrg, df, wl and pl as associated facies. It represents dunes constituted by sets that can reach more than $10 \mathrm{~m}$ and tens of metres of lateral extension (Fig. 13D). They commonly interact with fluvial sediments.

Architectural element E2 (Sandsheet): This element is constituted by ae4 and ae 5 main facies, with ss, df and wl as associated facies. It represents sandsheets constituting sets less than $1 \mathrm{~m}$ thick with flat and extensive base and some few tens of metres of lateral extension (Fig. 13 C).

Architectural element E3 (Interdune): This element is constituted by ae4 and ae6 main facies, with sbp, dc, wl, Fb and Fl as associated facies. It represents interdunes constituting irregular lenses of finegrained massive sandstones of pale-brown colour and occasional mottling (Fig. 13B).

\subsection{Characteristics of the sedimentary environments}

Fluvial and aeolian sedimentary environments are represented in both PUC and PLS units. Their characteristics have been defined based on the lateral and vertical evolution of their internal architectural elements (Fig. 4).

\subsubsection{Fluvial sedimentary environments}

PUC unit basically shows GB and GM elements. GB element represents gravel bars that usually are amalgamated constituting macroforms of about $1.5 \mathrm{~m}$ thick with erosive base and isolated internal sand

\begin{tabular}{|c|c|c|c|c|}
\hline \multicolumn{2}{|c|}{ Architectural elements } & Code & $\begin{array}{l}\text { Main facies and } \\
\text { associated facies }\end{array}$ & General morphology \\
\hline \multirow{3}{*}{$\begin{array}{c}0 \\
0 \\
-1 \\
0 \\
0 \\
0 \\
4\end{array}$} & $\begin{array}{l}\text { Dune. They form sets that } \\
\text { can reach more than } 10 \mathrm{~m} \text {. } \\
\text { They commonly interact with } \\
\text { fluvial sediments. }\end{array}$ & E1 & $\begin{array}{l}\text { ae1, ae2, ae3, ae4 } \\
a d, v s, d s, r s, s s r g \\
d f, w l, p l \\
\end{array}$ & $\left.\right|_{\text {Tens of meters of lateral extension }} ^{7 \mathrm{~m}}$ \\
\hline & $\begin{array}{l}\text { Sandsheet. They use to be less } \\
\text { than } 1 \mathrm{~m} \text { thick and may show } \\
\text { translatent-strata. Lateral extension } \\
\text { reaches some few tens of meters. }\end{array}$ & E2 & $\begin{array}{l}\mathrm{ae} 4, \mathrm{ae} 5 \\
s s, d f, w l\end{array}$ & $\left.\right|_{\text {Normally flat and extensive base }} ^{0.9 \mathrm{~m}}$ \\
\hline & $\begin{array}{l}\text { Interdune. They show irregular } \\
\text { lenses of fine-grained massive } \\
\text { sandstones of pale-brown color } \\
\text { with occasional mottling. }\end{array}$ & E3 & $\begin{array}{l}\text { ae4, ae6 } \\
S b p, F b, F l, d c, w l\end{array}$ & $\left.\right|_{\text {Usually flat base and erosive top }} ^{1.1 \mathrm{~m}}$ \\
\hline
\end{tabular}

Fig. 12. Defined aeolian architectural elements and their main sedimentary characteristics. 


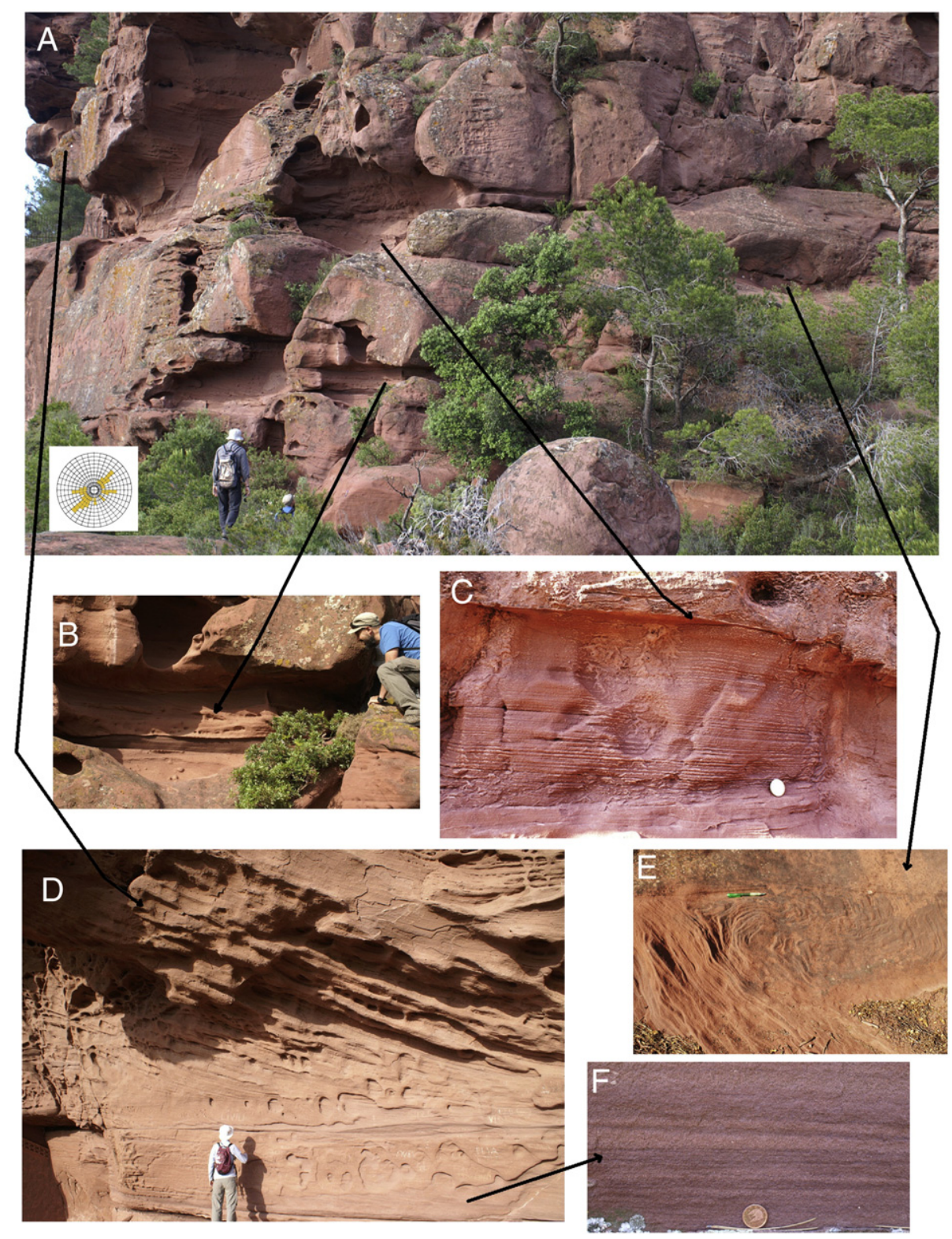

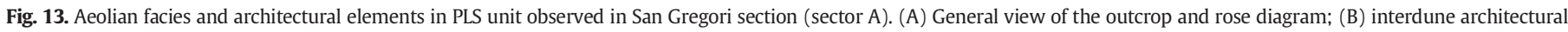

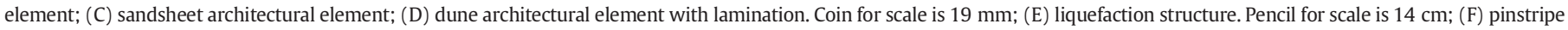
lamination Coin for scale of $13 \mathrm{~mm}$.

wedges. They are interpreted as channel-fill deposits in a shallow gravelly dominated fluvial system related to proximal-medial areas and periodical waning-flow stages, similar to examples described by Ramos and Sopeña (1993) and Rice et al. (2009). GM element is not abundant and it is rather located in the lower part of PUC unit. This element is interpreted as unconfined or semi-confined massive and individual gravelly bodies up to $0.8 \mathrm{~m}$ thick with crude horizontal stratification in proximal fluvial systems. Similar examples were defined by Miall (1978) and Davis and Gibling (2011). The latter authors also related this type of sediments to the absence of complexes of root assemblages. GM element may sporadically shows aeolian reworking when ae5 facies is located at the top of the gravelly bodies during stages with high wind velocity and restricted sediment availability in distal areas, similar to examples described by Rodríguez-López et al. (2012) in the Late Pliocene of the Teruel Basin, Spain.

Paleocurrents of PUC unit trend towards S-SE (Figs. 4, 6A). Readings are mainly obtained from planar cross-stratification structures. PLS unit shows a wide variety of architectural elements, including those of fluvial and aeolian origin. SB element is interpreted as mesoforms related to channel-fill deposits of sand-dominated river systems into wide areas of sedimentation. They predominantly accumulated by vertical aggradation of trains of individual bedforms (Ashley, 1990; Gibling and Rust, 1990). CH element is interpreted as channel-fill sandstone bodies showing internal erosive surfaces due to lateral shift of the sedimentary complex that frequently impede the recognition of channel margins (Gibling, 2006). They are related to proximal and medial areas in the fluvial system. FF element represents fine sandstone and lutite floodplain deposits. It is interpreted as non-channelized deposits related to overbank flooding (Bown and Kraus, 1987; Smith et al., 1989) in medial to distal areas of the fluvial system.

Paleocurrents of fluvial deposits of PLS unit range from ESE to SSE (Fig. 4). Measurements have been mainly obtained from planar and trough cross-stratification and locally from parting lineation structures.

\subsubsection{Aeolian sedimentary environments}

Sediments of aeolian origin in the PUC unit are very scarce and located as internal small sandy wedges with reduced lateral extent resulting in eroded small aeolian beds at the base of the unit (Fig. 6C). They 
represent flat-bedded sandstones (sandsheets) that originated during periods of high velocity winds, restricted sediment availability and stages of waning flows in the fluvial system, with temporary subaerial exposure and reworking of large tracts of sandy channel deposits.

PLS unit shows different aeolian architectural elements mainly in sector A (Fig. 4). Dune architectural element (E1) (Fig. 13D) is the dominating one in the western part of the study area, especially in San Gregori section. This element constitutes systems of superimposed morphologies with tens of metres of lateral extension with large to medium-scale sets of trough cross-strata of well-sorted grains formed during the migration of the slip-faces of the aeolian dunes (Hunter, 1977; Kocurek, 1981; Chrintz and Clemensen, 1993; Mountney, 2006; Rodríguez-López et al., 2010, 2011). They show commonly wellsorted, coarse-grained sand wedges merging with fine-grained or grain flow deposits, and wind ripple strata displaying characteristic pinstripe lamination (Fig. 13F). Ductile soft-sediment deformation structures (Fig. 13E) related to slumping of moderately cohesive and moist sands on the dune lee slope in response to surface precipitation (Doe and Dott, 1980) are also associated to the dune complex.

Sandsheet architectural element (E2) (Fig. 13C) is not frequently preserved in the study area. It shows less than ten metres of lateral extension before it disappears due to erosion. It is developed in areas of transition between fluvial to aeolian dominance (Kocurek and Nelson, 1986; Brookfield, 1992; Tripaldi and Limarino, 2008; Durand and Bourquin, 2013). The restricted sediment supply in these transitional areas could be responsible for the lateral development of these lowrelief morphologies (Mountney, 2006), while the variation of wind speed would favour the transition between plane-bed lamination and wind-ripple strata.

Interdune architectural element (E3) (Fig. 13B) only appears in San Gregori and Mont Roig sections, western part of sector A. It shows flat base, irregular top and important later erosion that impedes its lateral preservation as normally it is not more than $5 \mathrm{~m}$ long. This element represents interdune flats between aeolian dunes. They may be close to the capillary fringe of the water table in "wet" aeolian dune systems (Mountney, 2006, 2012), where bioturbation may be common (Loope, 1988; Hasiotis, 2002) as in the San Gregori section, of sector A.

Paleowinds trend not only towards the SW and $\mathrm{W}\left(220^{\circ}-230^{\circ}\right.$ and $\left.260^{\circ}-270^{\circ}\right)$ but also towards the NE and $\mathrm{E}\left(40^{\circ}-50^{\circ}\right.$ and $\left.90^{\circ}-100^{\circ}\right)$ (Figs. 4, 13A). These values are based on 37 measurements from localities that have been interpreted as former avalanching face dunes.

\subsubsection{Fluvial and aeolian sedimentary environments' interaction}

The Paleozoic basement formed important reliefs separating the Catalan Basin in three subbasins during the Early Triassic (Fig. 2). This structural subdivision was the main cause that controlled the distribution and development of the sedimentary environments. The general trend of the basin has an approximately SW-NE orientation and the Paleozoic paleorelief was probably very irregular showing different structural highs related to transversal faults to the main rift system axis (Fig. 14).

The westernmost Prades subbasin was the widest and most subsiding area where sedimentation reached the maximum thickness. The Garraf subbasin was a more isolated and confined area of sedimentation, but it was the focus of the earliest stages of subsidence during the Permian and contains the oldest sedimentary record. The Montseny subbasin probably represented an elevated area during the Permian and most of the Early Triassic, especially its easternmost side. In any case, the sedimentary record shows a clear interruption at the Permian-Triassic transition and also during the beginning of the Middle Triassic. In the easternmost area of the Montseny subbasin (El Figaró and El Brull areas), there is no sedimentary record during the Early Triassic.

The location of the architectural elements in the studied sections shows a general N-S proximal to distal distribution trend of sedimentation. During the first stages of the Triassic sedimentation in the Prades sector (PUC unit), proximal alluvial sediments and gravelly braided fluvial systems (GB element) developed in the more elevated areas (L'Albiol and Riera de St. Jaume areas), and were flowing southwards. These fluvial systems were controlled by $\mathrm{N}-\mathrm{S}$ oriented tectonic structures. Isolated alluvial fans in the proximal areas of these systems coming from elevated areas to the $\mathrm{W}$ were probably common. The absence of vegetation would make easier the deposition of unconfined beds (GM element).

Medial areas of sedimentation were represented by sandy braided fluvial systems development and were connected with aeolian systems during later stages of sedimentation (PLS unit), such as in the Mont Roig and Cervelló sections (Fig. 14). Sandy fluvial systems (SB, CH and FF elements) evolved as unconfined systems in the Prades subbasin. The scarce presence of vegetation allowed extensive lateral development of the fluvial systems similar to examples described by Bourquin et al. (2011) and López-Gómez et al. (2012) in similar Triassic red beds of Central Europe, Lodeve Basin (SE France) and Iberian Basin (E Spain).

Fluvial and aeolian sedimentary environments' interactions are related to a narrow belt developed between Mont Roig and L'Albiol area, in the Prades subbasin. This belt shows a progressive downstream decrease in discharge and flow competency. Vertical alternating beds of fluvial and aeolian origin demonstrate frequent changes of sedimentary environment style in this interaction area, similar to the alternating stacked beds described in the Permian red beds of the Organ Rock Fm. SE Utah, USA (Cain and Mountney, 2009, 2011) and Paganzo Basin, Argentina (Spalletti et al., 2010).
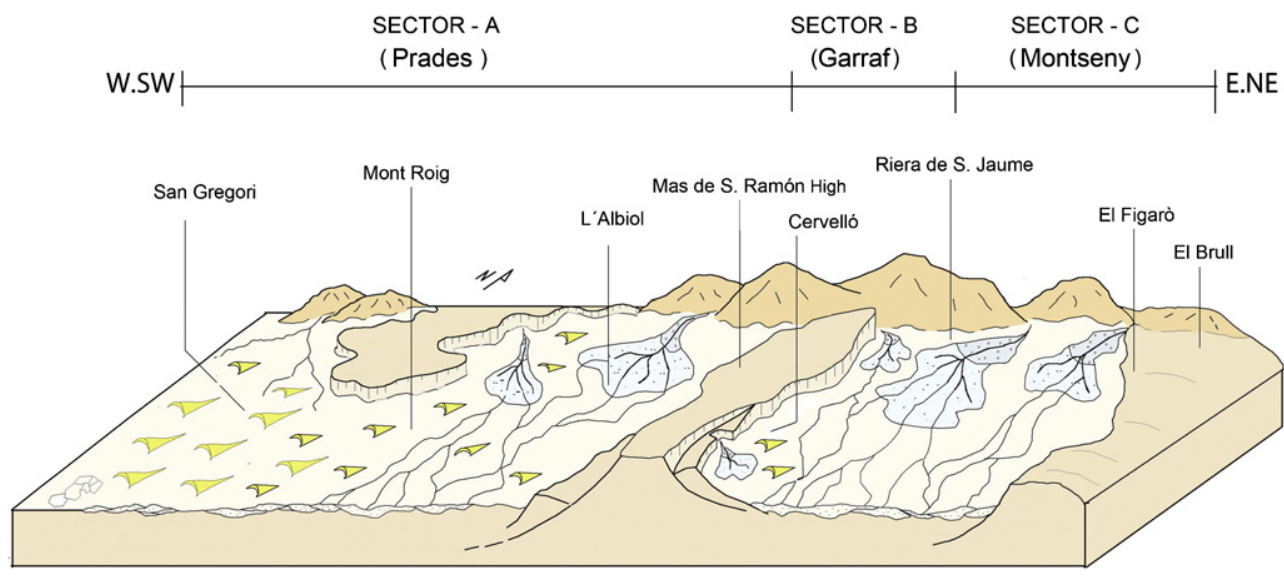

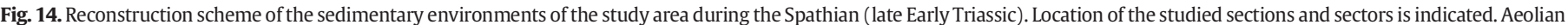

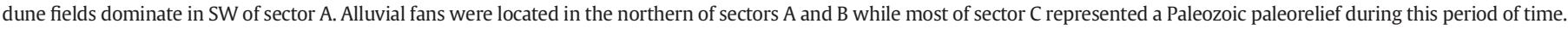

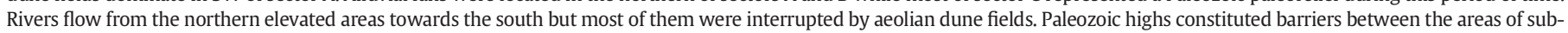
sidence in the three subbasins. 
Aeolian sediments were extensively developed in the eastern area of the Prades subbasin. Wide dune fields migrating with sporadic interruptions were fed by high discharges of ephemeral braided rivers, probably a situation similar to present-day Hoanib River passing to interdunal depressions in the Namib Desert (Stanistreet and Stollhofen, 2002), or to Late Pliocene intracontinental aeolian dune field of Teruel Basin, Spain (cf. Rodríguez-López et al., 2012). Episodic floodings and changes in groundwater table could have conditioned the geometry and extension of interdune areas (Mountney and Thompson, 2002). Dune fields grew southwards and were controlled by prevailing winds and the eastwards positive topography represented by the Mas de Ramón high (Fig. 14).

\section{Palaeontological content and age}

Geochemical changes of the carbon cycle most likely related to large volcanic episodes from the Siberian Traps during the Permian-Triassic boundary, and protracted during the Early Triassic during at least four episodes (Xie et al., 2010), caused the important absence of life in most of the continental environments of the Earth during this time (Pruss and Bottjer, 2005; Chen et al., 2007; Hermann et al., 2011; Shen et al., 2012). Connections of these perturbations with drastic environmental changes and the delay of the post-extinction recovery are widely accepted (Payne et al., 2004; Pruss et al., 2005; Song et al., 2013). The fossil content of the Lower Triassic sedimentary record in the Catalan Ranges also reflects these perturbations, and only in the upper 2 cycle, already in the Anisian, this content starts to be common. Therefore, the scarce fossil content is neither enough nor representative for obtaining a precise age for the beginning of the Buntsandstein facies sedimentary cycle in the Catalan Ranges.

Although there is a lack of any fossil up to now in the PUC unit (Calvet and Marzo, 1994; López-Gómez et al., 2002) and there is neither any paleontological record in the PLS allowing any precise data of the age of these sediments, it is however important to note that the presence of the first bioturbation horizons and a fossil plant (Pleuromeia) described by Galán-Abellán (2011) in the upper part of this latter unit, representing the oldest biotic record in the Mesozoic of the Catalan Ranges and the first signals of life recovery after the crisis of the Permian-Triassic boundary in this area.

The presence of bioturbation horizons, rootlet imprints and palynological assemblages are more frequent in the upper part of the coeval Cañizar Fm. in the Iberian Ranges (López-Gómez et al., 2012), indicating an earlier start for the biotic recovery in this area, favoured by the presence of broad, perennial rivers, a more friendly environment for life than the arid deserts in NE Iberia. The transition from hyper-arid environments in the NE to more humid, seasonal environments to the SW can be placed in a narrow belt running from the Ateca-Montalbán Paleozoic high to the SE of it, in the Castilian Branch of the southern Iberian Ranges (Fig. 15), where aeolian sediments are very scarce (LópezGómez et al., 2012).

PUC and PLS units are broadly equivalent to the Riera de San Jaume megasequence of the southern part of sector $\mathrm{C}$, where the equivalent to PLS unit shows alternating siltstones and sandstones beds in its upper part (Fig. 2) (Calvet and Marzo, 1994). Magnetostratigraphic studies in this megasequence indicate a Spathian (late Olenekian) age for most of the Riera de San Jaume sequence, with an Aegian (early Anisian) age for its uppermost part, and Bithynian to Illyrian age for El Figarò s.s (Dinarès-Turell et al., 2005). However, we consider the lower part of the Buntsandstein sedimentary cycle could be of Smithian age when the general characteristics of the sedimentary succession are compared to those of similar successions of neighbour basins of Spain and SE France described by Péron et al. (2005), Bourquin et al. (2011) and López-Gómez et al. (2012). Studies based on tetrapod bones and footprints (Calzada, 1987; Gaete et al., 1994; Fortuny et al., 2011) in the overlying El Figaró Lutites and Sandstones unit, allowed to establish lithostratigraphic correlations with units of the neighbouring Iberian

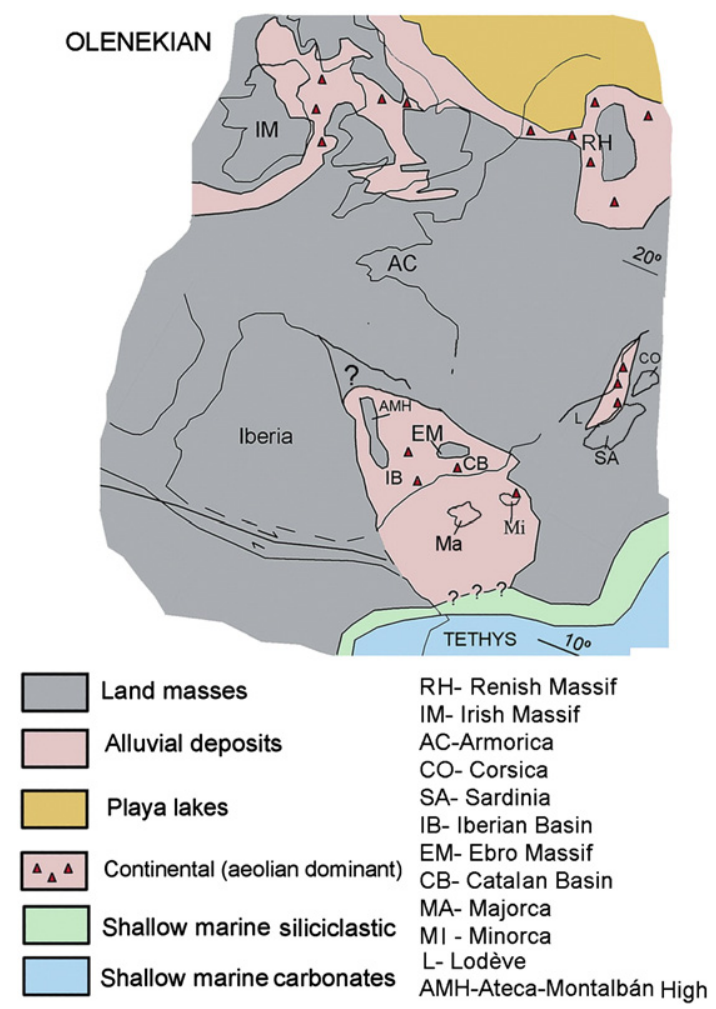

Fig. 15. Palaeogeographical reconstruction of the Catalan and neighbour basins in centraleast Pangea for the Olenekian (late Early Triassic). The sedimentation of NE Iberia area was dominated by alternating fluvial and aeolian environments controlled by different paleotopographic highs and subsiding basins that were progressively linked to other rifting systems towards the north. Information of geographical location, palaeolatitudes and sedimentary environments are partially based on Ziegler (1988), Dercourt et al. (1993), Swiecicki et al. (1995), Geluk and Röhling (1997), Stampfli and Borel (2002), McKie and Williams (2009), Bourquin et al. (2011), McKie and Shannon (2011), Sánchez-Martínez et al. (2012) and Tyrrell et al. (2012).

basin (Arche et al., 2004; Bourquin et al., 2011; Galán-Abellán, 2011), corroborating this age.

\section{Palaeogeographical considerations and discussion}

The beginning of the Triassic in Western Europe is basically represented by sediments of continental origin. In this area, the Permian and Triassic succession record is also marked by a hiatus and/or unconformity between both periods. Questions related to the precise age of the continental Triassic sediments, abrupt climate changes and pulses of life recovery are still unresolved (Díez et al., 2005, 2007; Durand, 2006, 2008; Bourquin et al., 2007; Cassinis et al., 2007, 2009, 2012; López-Gómez et al., 2012). The palaeogeographical location and the sedimentary characteristics of the Catalan Basin during the Triassic may shed light on some of these questions.

At the end of Early Triassic, the Catalan Basin was located at about $8^{\circ} \mathrm{N}$ paleolatitude (Dinarés-Turell et al., 2005) (Fig. 15). In this location the basin could have represented a local geographical connection between basins in Iberia and Central Europe or other related areas, such as the Labrador area, as recently described by Sánchez-Martínez et al. (2012). This stage could be related to the beginning of the megacontinent break-up and subsequent development of intraplate corridors. The central part of Pangea was mainly constituted by land masses still covered by mountain belts related to the Variscan Belt (Bourquin et al., 2011). Although these mountain belts were probably not very high during the Early Triassic (Fluteau et al., 2003) they could had controlled not only the water supply to the basins and local climate (Ulicný, 2004), but also the migration of reptiles across Central Europe (Diedrich, 2008) during most of the Spathian (late Early Triassic). This 
latter author also considers that the initial break-up of Pangea already had started in the Middle Triassic (Diedrich, 2009), and that event had begun to drastically change environments all over Central Europe, when dinosaurs began to diversify, probably as a direct reaction to environmental changes related to barriers' control.

The Catalan Basin and the rest of sedimentary basins of the Iberian plate were irregularly interconnected among them during the late Early Triassic (López-Gómez et al., 2012). These connections were locally and temporally interrupted by Paleozoic paleoreliefs that also internally subdivided the different basins, as was the case of the subbasins into the Catalan Basin. The sedimentary record in these subbasins indicates different tectonic regimes during their development in the rift system, as subbasins were separated by positive barriers acting as highs between them. Earliest stages of subsidence probably started in sector $\mathrm{B}$, already during the Late Permian and continued during the Early Triassic, while most of the sector $C$ remained as a high area during this period of time. However, the beginning of the Anisian showed a reversed development of the subbasins with faster subsidence in the northern area, sector $\mathrm{C}$, where interruptions during sedimentation were less frequent.

The Catalan Basin was separated from the central European Plate by the narrow but laterally extensive Pyrenees High towards the north, and from the Ebro Basin by the Ebro Massif towards the west (Roca et al., 1999; Gaspar-Escribano et al., 2004). Corridors were related to rift basins development that extended their branches connecting basins in mature stages of subsidence (Vargas et al., 2009).

The beginning of the Triassic sedimentation in the Catalan Basin was related to the end of a dry episode during the late Smithian well described in Central and Western Europe (Kidder and Worsley, 2004; Péron et al., 2005; Durand, 2006; Bourquin et al., 2007, 2011; Cassinis et al., 2007; Galfetti et al., 2007; Preto et al., 2010) and also at the global scale (i.e. Chen et al., 2013), probably caused by the still elevated $\mathrm{CO}_{2}$ values related to coeval episodic volcanic activity well after the emplacement of the Siberian Traps (Payne and Krump, 2007; Brühwiler et al., 2009). A cooler episode characterized the beginning of the Spathian (Szurlies, 2007; Romano et al., 2013) when paleosoils and tetrapod footprints were developed in Central Pangea (Haubold, 1983; Fichter and Kunz, 2004). However, the middle Spathian also shows an arid to hyper-arid episode in Central-Western Europe interrupting the general cooling tendency (Röhling, 1991; Bourquin et al., 2006, 2009; Ghinassi et al., 2009; López-Gómez et al., 2012). This arid episode is well recorded by the development of dune field deposits in the southern Catalan Basin which was coetaneous with other similar aeolian dune fields in Central-Western Pangea as described by Geluk (1998), Cassinis et al. (2003), Bourquin et al. (2007, 2011), Durand (2008), Linol et al. (2009), McKie and Williams (2009) and Soria et al. (2011).

Sedimentary study in this work shows how aeolian facies increase southwards in the Catalan Basin, it is, downwards of the river systems draining, where dune fields were developed, as happened in San Gregori and Mont Roig areas, in the southern Sector A. These braided river systems probably ended as endorheic, terminal semi-arid fluvial systems in the interdune areas of the aeolian dune fields, similar to recent examples described in the Namib Sand Sea by Lancaster and Teller (1988).

Some of these rivers would not probably link to other fluvial systems and neither would reach the Tethys coast, so they can be considered terminal rivers at the distal end (Fig. 15). Other similar fluvial-aeolian interaction systems were also developed in neighbouring areas of the Catalan Basin during the late Smithian-Spathian, as those described in Sardinia (Cassinis et al., 2003; Ghinassi et al., 2009), Minorca Island (Linol et al., 2009), Provence Basin, southern Massif Central (Durand, 2006, 2008), northern Iberian Basin (Soria et al., 2011) or Benicassim area, eastern Iberian Basin, Spain (López-Gómez et al., 2012). Ventifacts have been also described in all these latter basins related to a hyper-arid period which can be constrained to be around this period of time. First attempts to stratigraphically correlate all these areas can be found in
Ronchi et al. (2008a, b), Ronchi et al. (2009) and Bourquin et al. $(2007,2011)$. It is important to remark that a reduced run off and related scarce sediment flux towards the Tethys occurred under these conditions, and probably delta systems would not be developed at the distal end of the fluvial network (Fig. 15).

Early Triassic fauna and flora diversity in the Catalan Basin were severely reduced probably due to the still prevailing general perturbations in the continental ecosystems of Pangea (Sun et al., 2012). Harsh climate conditions forced internal migrations of fauna using the new created corridors developed in the generalized rifting process during the late Olenekian-Anisian. These connected rift branches in the centre of this megacontinent linked basins that started to experience the same tectonic events, such as the recorded by the Hardegsen unconformity, which is very well recorded in Central Europe (Aigner and Bachmann, 1992; Geluk and Röhling, 1997; Bourquin et al., 2007, 2011; Bachmann et al., 2010) and probably represents one of the most important tectonic events of Central Pangea during the Early Triassic. This tectonic phase, probably represented by a series of unconformities and related to NNE-SSW trending tensional and transtensional deformation was driven by intra-plate stress build-up (Geluk, 1998; Bachmann et al., 2010). This phase has also been recognized in the upper third part of the Cañizar Formation (Iberian Ranges), Central Spain, where it is not just an unconformity but it is also representing the beginning of life recovery in this area after the crisis of the Permian-Triassic boundary (LópezGómez et al., 2012). This latter formation has been considered as the lateral equivalent to the PLS unit of the Catalan Ranges (Arche et al., 2004; Ronchi et al., 2009; Bourquin et al., 2011; Galán-Abellán, 2011). Although there is not a clear differentiated unconformity in the upper third part of the PLS unit, the above indicated equivalence between the units and the age and the first Triassic fossils and bioturbation horizons found in this part of the PLS unit, allow us also to consider the influence of the late Olenekian-Anisian tectonic activity and rifts connections, and its related faunal migrations of Central Europe, to the Catalan Basin.

Fig. 15 shows the aeolian dune field distribution during the Smithian-Spathian in Iberia and adjacent areas of the western Tethys, and the palaeogeographical configuration of the Catalan and neighbouring basins at that time. Aeolian dune fields were common between $10^{\circ}$ and $30^{\circ} \mathrm{N}$ latitudes (McKie and Williams, 2009; Stolfová and Shannon, 2009; McKie, 2011; McKie and Shannon, 2011; Tyrrell et al., 2012), however they were disappearing southwards, towards the low Southern Hemisphere latitudes (Woods, 2005), where fluvial systems were better developed. This gradual change was also controlled by the existing topography. For instance, the Variscan Belt was still prominent in the area from Armorica to the southern Renish High (Fig. 15) and separated the northern and southern aeolian field domains (Bourquin et al., 2011). But also smaller highs, as those here described of eastern Iberia, represented barriers and created shadow areas for the dominating winds, as the Mas de San Ramón High, separating sectors A and B in the Catalan Basin (Fig. 14), and the southern Ateca-Montalbán High (Soria et al., 2011), that represented a barrier separating the aeolian dune fields of the northern Iberian Basin from the dominating fluvial systems of the southern Iberian Basin (López-Gómez et al., 2012) (Fig. 15). These two latter elevated areas probably constituted a corridor for the dominating winds where dune fields developed in both southern Catalan Basin and northern Iberian Basin, similar to the example described in the Pleistocene Hvar Island, Croatia, by Pavelic et al. (2011). This corridor probably allowed the accumulation of the southernmost dune fields of the northern hemisphere in Central-Eastern Pangea at the end of the Early Triassic.

The source of sand of the Early Triassic aeolian dune fields of Pangea is controversial as it is not clear whether the sand derived from near or remote areas. Dominant winds came from the east, probably following the corridor of the Tethys Sea in this latitude (Péron et al., 2005). The uniform composition of the dune sands in the Catalan Ranges could indicate only one source area, but not a constant source of sand. Sand 
could have a long residence time within the same area, reaching even more than one million years, as in the present-day Namib Desert (Vermeesch et al., 2010). In the southern Iberian Ranges, the timeequivalent rocks are of fluvial origin, however, they locally show aeolian reworked grains and thin horizons constituting part of the sandy fluvial bars (López-Gómez et al., 2012). It indicates that winds could punctually transport sands from the separated aeolian fields to the $\mathrm{N}$ to the fluvial sedimentary environments into the $S$, passing over the highs that were separating the subbasins. Connections of these two sedimentary environments should be common in the northern peri-Tethys area probably dominant not only during the Smithian (Péron et al., 2005; Bourquin et al., 2011) but also during the Spathian, by land or even by wind transport.

\section{Conclusions}

The beginning of the Buntsandstein sedimentary record in the Catalan Ranges is of late Smithian-early Anisian age and it is represented by a continental sequence constituted, from base to top, by the conglomerates and sandstones of the PUC and the PLS units in the Prades sector, GUC and the ES units in the Garraf sector and the RSJS in the Montseny sector. A detailed sedimentary analysis relates the PUC unit to gravely braided fluvial sedimentation with punctual aeolian reworking and connected to alluvial fans in proximal areas, and the PLS unit to intercalated aeolian and sandy braided fluvial systems. Sedimentation was recorded in a rift basin and controlled by the individual development of three differentiated NE-SW oriented subbasins: Montseny, Garraf and Prades respectively.

Sedimentation in the Catalan Basin occurred under arid to semiarid climate conditions, similar to those of the same age described in Central Europe. Dune fields of the Catalan Basin and neighbour areas represented the southernmost border of the huge arid area developed in Central Europe not only during the Smithian but also during the Spathian.

Dune fields were developed not only by dominant winds coming from the E and NE, but also by occasional winds coming from opposite azimuths. Sedimentation in the Catalan Basin was controlled by the Paleozoic highs that constituted barriers separating the three different subbasins. Paleocurrents of the fluvial system point southwards, but in the southern Prades subbasin they were interrupted by aeolian dune fields at short distances from their source areas. During the late Smithian-Spathian, the sediment supply of the river systems from the Catalan Basin and other neighbouring areas was scarce and endorreic, probably not reaching the western Tethys area.

In the Catalan Basin, the fossil content and bioturbation structures are very scarce and are only found in the upper part of the PLS unit. However, this fossil content and the previous lateral correlations established between the Catalan Ranges sections and those of contiguous basins allow a correlation of the first signals of life recovery after the Permian-Triassic boundary crisis.

These first signals of life recovery were related to the rapid development and connection of rift branches through the wide extensions of Central Pangea and peripheral areas during the late Olenekian-early Anisian, when paleogeographical barriers were reduced allowing fauna diversity and an easier migration.

\section{Acknowledgements}

This work has been supported by projects: CGL2011-24048 (Spanish Ministry), CSIC Researching Groups "Sistemas Sedimentarios y Variabilidad Climática” (642853), and UCM-BSCH-GR58/08 Projects: Análisis de Cuencas (910429) and Paleoclimas (910198). We thank the Editor, Brian Jones, and reviewer Ausonio Ronchi (Universitá di Pavia) and another anonymous reviewer for doing a detailed and interesting work for improving this manuscript. We also thank $\mathrm{M}^{\mathrm{a}}$ Isabel Benito (IGEO-UCM, CSIC) for her comments on the petrography, and
Sylvie Bourquin (Rennes Universitè) and Marc Durand for their interesting discussions in the field.

\section{References}

Aigner, T., Bachmann, G.H., 1992. Sequence-stratigraphic framework of the German Triassic. Sediment. Geol. 80, 115-135.

Anadón, P., Colombo, F., Esteban, M., Marzo, M., Robles, S., Santanach, P., Sugrañés, L., 1979 Evolución tectonoestratigráfica de los Catalánides. Acta Geol. Hisp. 14, 242-270.

Arche, A., López-Gómez, J., 1996. Origin of the Permian-Triassic Iberian Basin, Central Spain. Tectonophysics 266, 433-464.

Arche, A., López-Gómez, J., 2005. Sudden changes in fluvial style across the PermianTriassic boundary in the Eastern Iberian Ranges, Spain: analysis of possible causes. Palaeogeogr. Palaeoclimatol. Palaeoecol. 229, 104-126.

Arche, A., López-Gómez, J., Marzo, M., Vargas, H., 2004. The siliciclastic Permian-Triassic deposits in central and northeastern Iberian Peninsula (Iberian, Ebro and Catalan Basins): a proposal for correlation. Geol. Acta 2, 305-320.

Ashley, G.M., 1990. Classification of large-scale subaqueous bedforms: a new look at the old problem. J. Sediment. Petrol. 60, 160-172.

Atudorei, V., Baud, A., 1997. Carbon isotope events during the Triassic. Albertiana 20, 45-49.

Bachmann, G.H., Geluk, M.C., Warrington, G., Becker-Roman, A., Beutler, G., Hagdorn, H. Hounslow, M.W., Nitsch, E., Röling, H.-G., Simon, T., Szulk, A., 2010. Triassic. In: Doornenbal, J.C., Stevenson, A.G. (Eds.), Petroleum Geological Atlas of the Southern Permian Basin Area. EAGE Publications b.v., Houten, pp. 149-173.

Benton, M.J., 2003. When Life Nearly Died. The Greatest Mass Extinction of All Time. Thames \& Hudson, London (336 pp.).

Bottjer, D.J., Clapham, M.E., Fraiser, M.L., Powers, C.M., 2008. Understanding the mechanisms for the end-Permian mass extinction and the protracted Early Triassic aftermath and recovery. GSA Today 18 (9), 4-10.

Bourquin, S., Péron, S., Durand, M., 2006. Lower Triassic sequence stratigraphy of the western part of the Germanic Basin (west of Black Forest): fluvial system evolution through time and space. Sediment. Geol. 186, 187-211.

Bourquin, S., Durand, M., Díez, J.B., Broutin, J., Fluteau, F., 2007. The Permian-Triassic boundary and lower Triassic sedimentation in the western European basins: an overview. J. Iber. Geol. 33, 221-236.

Bourquin, S., Guillocheau, F., Péron, S., 2009. Braided river within an arid alluvial plain (example from the Early Triassic, western German Basin): criteria of recognition and expression of stratigraphic cycles. Sedimentology 56, 2235-2264.

Bourquin, S., Bercovici, A., López-Gómez, J., Díez, J.B., Broutin, J., Ronchi, A., Durand, M., Arche, A., Linol, B., Amour, F., 2011. The Permian-Triassic transition and the onset of Mesozoic sedimentation at the northwestern peri-Tethyan domain scale: palaeogeographic maps and geodynamic implications. Palaeogeogr. Palaeoclimatol. Palaeoecol. 299, 265-280.

Bown, T.M., Kraus, M., 1987. Integration of channel and floodplain suits. I. Development of sequence and lateral relations of alluvial paleosols. J. Sediment. Petrol. 57, 587-601.

Brookfield, M.E., 1992. Eolian systems. In: Walker, R.G., James, N.P. (Eds.), Facies Models. Response to Sea Level Change. Geological Association of Canada, pp. 143-156.

Brühwiler, T., Goudemand, N., Galfetti, T., Bucher, H., Baud, A., Ware, D., Hermann, E., Hochuli, P.A., Martín, R., 2009. The Lower Triassic sedimentary and carbon isotope records from Tulong (South Tibet) and their significance for Tethyan palaeoceanography Sediment. Geol. 222, 314-332.

Cain, S.A., Mountney, N.P., 2009. Spatial and temporal evolution of a terminal fluvial fan system: the Permian Organ Rock Formation, south-east UTA, USA. Sedimentology 56, 1774-1800.

Cain, S.A., Mountney, N.P., 2011. Downstream changes and associated fluvial-aeolian interactions in an ancient terminal fluvial system: The Permian Organ Rock Formation, SE Utah, U.S.A. In: Davidson, S.K., Leleu, S. (Eds.), From river to rock record: the preservation of fluvial sedimentation and their subsequent interpretation. SEPM (Society for Sedimentary Geology) Special Publication, 97, pp. 167-185.

Calvet, F., Marzo, M., 1994. El Triásico de las Cordilleras Costero Catalanas: Estratigrafía Sedimentología y Análisis Secuencial. In: Arche, A. (Ed.), Conferencia de Estratigrafía y Paleogeografía del Pérmico y Triásico de España. Field trip guide (Cuenca, 53 pp.).

Calvet, F., Tucker, M., Henton, J., 1990. Middle Triassic carbonate ramp systems in the Catalan Basin, northeast Spain: facies, systems tracks, sequences and controls. In: Tucker, M., Wilson, J., Crevello, P., Sarg, J., Read, J. (Eds.), Carbonate Platforms. Special Publication of the International Association of Sedimentologists, 9, pp. 79-108.

Calzada, S., 1987. Niveles fosilíferos de la facies Buntsandstein (Trias) en el sector norte de los Catalánides. Cuad. Geol. Iber. 11, 256-271.

Cassinis, G., Durand, M., Ronchi, A., 2003. Permian-Triassic continental sequences of northwest Sardinia and south Provence: stratigraphic correlations and paleogeographic implications. In: Decandia, F.A., Cassinis, G., Spina, A. (Eds.), Late Palaeozoic to Early Mesozoic Events of Mediterranean Europe, an Additional Regional Reports. Siena 2011. Boll. Soc. Geol. Ital., 2, pp. 119-129.

Cassinis, G., Durand, M., Ronchi, A., 2007. Remarks on the Permian and Permian-Triassic boundary in central and eastern Lambardy (Southern Alps, Italy). J. Iber. Geol. 33 (2), 133-142.

Cassinis, G., Durand, M., Ronchi, A., 2009. Reply to discussion on the article "remarks on the Permian and Permian-Triassic boundary in central and eastern Lombardy (Southern Alps, Italy)". J. Iber. Geol. 35 (1), 73-78.

Cassinis, G., Perotti, C., Ronchi, A., 2012. Permian continental basins in the Southern Alps (Italy) and peri-Mediterranean correlations. Int. J. Earth Sci. 101, 129-150.

Chen, Z.Q., Tong, J., Kaiho, K., Kawahata, H., 2007. Onset of biotic and environmental recovery from the end-Permian mass extinction within 1-2 million years: a case 
study of the Lower Triassic of the Meishan section, South China. Palaeogeogr Palaeoclimatol. Palaeoecol. 352, 176-187.

Chen, Y., Twitchett, R.J., Jiang, H., Richoz, S., Lai, X., Yan, Ch., Sun, Y., Liu, X., Wang, L., 2013. Size variations of conodonts during the Smithian-Spathian global warming event (Early Triassic). Geology online 28 June . http://dx.doi.org/10.1130/G34171.1.

Chrintz, T., Clemensen, L.B., 1993. Draa reconstruction, the Permian Yellow Sand, northeast England. In: Pye, K., Lancaster, N. (Eds.), Aeolian Sediments, Ancient and Modern. International Association of Mineralogists, pp. 51-161 (Special Publication 16).

Clemmensen, L.B., 1978. Alternating aeolian, sabkha and playa-lake deposits from the Middle Triassic, Gipsdalen Formation, Scoresby Land, East Greenland. Palaeogeogr. Palaeoclimatol. Palaeoecol. 36, 125-153.

Davis, N., Gibling, M., 2011. Evolution of fixed-channel alluvial plains in response to Carboniferous vegetation. Nat. Geosci. 4, 629-633.

De Vicente, G., Vegas, R., Muñoz-Martín, A., Van Wees, J.D., Casa-Sainz, A., Sopeña, A., Sánchez-Moya, Y., Arche, A., López-Gómez, J., Olaiz, A., Fernández-Lozano, J., 2009. Oblique strain partitioning and transpression on an inverted rift: the Castilian Branch of the Iberian Chain. Tectonophysics 470, 224-242.

Dercourt, J., Ricou, L.E., Vrielynck, B., 1993. Atlas Tethys Palaeoenvironmental Maps. Beicip-Fronlab, Rueil Malnaison.

Diedrich, C., 2008. Millions of reptile tracks-Early to Middle Triassic carbonate tidal flat migration bridges of Central Europe. Palaeogeogr. Palaeoclimatol. Palaeoecol. 259, 410-423.

Diedrich, C., 2009. Palaeogeographic evolution of the marine Middle Triassic Germanic Basin changements-with emphasis on the carbonate tidal flat and shallow marine habitats of reptiles in Central Pangea. Glob. Planet. Chang. 65, 27-55.

Díez, J.B., Broutin, J., Ferrer, J., 2005. Difficulties encountered in defining the PermianTriassic boundary in Buntsandstein facies of the western Peritethyan domain based on palynological data. Palaeogeogr. Palaeoclimatol. Palaeoecol. 229, 40-53.

Díez, J.B., Bourquin, S., Broutin, J., Ferrer, J., 2007. The Iberian Permian-Triassic "Buntsandstein" of the Aragonian branch of the Iberian Range (Spain) in WestEuropean sequence stratigraphical framework: a combined palynological and sedimentological approach. Bull. Soc. Geol. Fr. 2007 (178), 187-203.

Díez, J., Escudero, M.J., Galán-Abellán, B., López-Gómez, J., Barrenechea, J., Marzo, M. Martín-Chivelet, J., 2012. Nuevos registros palinológicos en facies Röt de la Rama Aragonesa de la Cordillera Ibérica y Cadenas Costero Catalanas (NE Península Ibérica). Abstract book Agora Paleobotánica. Lyon, 21-22 Junio 201211

Dinarès-Turell, J., Díez, J.B., Rey, D., Arnal, I., 2005. “Buntsandstein” magnetostratigraphy and biostratigraphic reappraisal from eastern Iberia: Early and Middle Triassic stage boundary definitions through correlation to Tethyan sections. Palaeogeogr. Palaeoclimatol. Palaeoecol. 229, 158-177.

Doe, T.W., Dott Jr., R.H., 1980. Genetic significance of deformed cross bedding - with examples from the Navajo and Weber Sandstones of Utah. J. Sediment. Petrol. 50, 793-811.

Durand, M, 2006. The problem of the transition from the Permian to the Triassic series in southeastern France: comparison with other Perithethyan regions. In: Lucas, S.G. Cassinis, G., Schneider, J.W. (Eds.), Non-Marine Permian Biostratigraphy and Biochronology. Geol. Soc. Spec. Publ., 265, pp. 281-295.

Durand, M., 2008. Permian to Triassic continental successions in southern Provence (France): an overview. Boll. Soc. Geol. Ital. 127, 697-716.

Durand, M., Bourquin, S., 2013. Criteria for the identification of ventifacts in the geological record: a review and new insights. C. R. Geosci. 345, 111-125.

Erwin, D.H., 1993. The Great Paleozoic Crisis: Life and Death in the Permian. Columbia University Press, New York (327 pp.)

Erwin, D.H., 2006. Extinction. How Life on Earth Nearly Ended 250 Million Years Ago. Princeton University Press, Princeton, Oxford (296 pp.).

Fichter, J., Kunz, R., 2004. New genus and species of chirotheroid tracks in the DetfurthFormation (Middle Bunter, Lower Triassic of Central Germany) Germany. Ichnos 11 $183-193$.

Fluteau, F., Basse, J., Broutin, J., Ramstein, G., 2003. The Late Permian climate. What can be inferred from climate modeling concerning Pangea scenarios and Hercynian range altitude? Palaeogeogr. Palaeoclimatol. Palaeoecol. 167, 30-71.

Fortuny, J., Bolet, A., Sellés, A., Cartanyà, J., Galobart, À., 2011. New insights on the Permian and Triassic vertebrates from the Iberian Peninsula with emphasis on the Pyrenean and Catalonian basins. J. Iber. Geol. 37 (1), 65-87.

Gaete, R., Galobart, A., Palomar, J., Marzo, M., 1994. Hallazgo de Paratosuchus sp. (Amphibia, Temnospondyli) en facies Buntsandstein del Pla de la Calma (Cordilleras Costero Catalanas): Resultados preliminares. Geogaceta 16, 61-63.

Galán-Abellán, A.B.., 2011. Sedimentary, Mineralogical and Geochemical Variations in the Buntsandstein Facies, Lower-Middle Triassic, of the Iberian Ranges and Catalan Coastal Ranges: Implications in the Recovery of the Permian-Triassic Crisis. Ph.D Thesis. Universidad Complutense, Madrid. 383pp. Unpublished.

Galán-Abellán, B., Barrenechea, J.F., Benito, M.I., De la Horra, R. Luque, J., Alonso-Azcárate J., Arche, A., López-Gómez, J., Lago, M., 2013. Palaeoenvironmental implications of aluminium phosphate-sulphate minerals in Early-Middle Triassic continental sediments, SE Iberian Range (Spain). Sediment. Geol. 289, 169-181.

Galfetti, T., Hochuli, P., Brayard, A., Bucher, H., Weissert, H., Os Vigran, J., 2007. SmithianSpathian boundary event: evidence for global climatic change in the wake of the endPermian biotic crisis. Geology 35 (4), 291-294.

Gaspar-Escribano, J., van Wees, J.D., ter Voorde, M., Cloetingh, S., Roca, E., Cabrera, L. Muñoz, J.A., Ziegler, P.A., García-Castellanos, C., 2001. 3D flexural modeling of the Ebro Basin (NE Iberia). Geophys. J. Int. 145, 349-367.

Gaspar-Escribano, J., García-Castellanos, C., Roca, E., Cloetingh, S., 2004. Cenozoic vertica motions of the Catalan Coastal Ranges (NE Spain): the role of tectonics, isostasy, and surface transport. Tectonics 23, 1-18.

Geluk, M.C., 1998. Palaeogeographic and structural developments of the Triassic in the Netherlands - new insights. In: Bachmann, G.H., Lerche, I. (Eds.), Epicontinenta Triassic 1. Zbl. Geol. Paläont. Teil, 1, pp. 545-570.
Geluk, M.C., Röhling, H.G 1997. High-resolution séquense stratigraphy of the Lower Triassic Buntsandstein: a new tool for basin análisis. In: Bachmann, G.H., Lerche, I. (Eds.), Epicontinental Triassic. Zbl. Geol. Paläontol., 1, pp. 727-745 (7-8)

Ghinassi, M., Durand, M., Ronchi, A., Stefani, C., 2009. Permian-Middle Triassic continental succession of NW Sardinia. In: Pascucci, V., Andreucci, S. (Eds.). Field Trip Guidebook. Preconference trip FT3 27th IAS Meeting of Sedimentology, Alguero 20-23 September, pp. 37-50.

Gibling, M.R., 2006. Width and thickness of fluvial channel bodies and valley fills in the geological record: a literature compilation and classification. J. Sediment. Res. 76, 731-770.

Gibling, M.R., Rust, B.R., 1990. Ribbon sandstones in the Pennsylvanian Waddens Cove Formation, Sydney Basin, Atlantic Canada: The influence of siliceous duricrusts in channel-body geometry. Sedimentology 37, 45-65.

Gómez-Gras, D., 1993. El Permotrías de la Cordillera Costero Catalana: Facies y petrología sedimentaria (parte I). Bol. Geol. Min. 104, 115-161.

Hasiotis, S.T., 2002. Continental Trace Fossils: SEPM, Short Course Notes 51 (132 pp.)

Haubold, H., 1983. Archosaur evidence in the Buntsandstein (Lower Triassic). Acta Palaeontol. Pol. 28, 123-132.

Hermann, E., Hochuli, P.A., Bucher, H., Brühwiler, T., Hautmann, M., Ware, D., Roohi, G., 2011. Terrestrial ecosystems on North Gondwana following the end-Permian mass extinction. Gondwana Res. 20, 630-637.

Hunter, R.E., 1977. Basic types of stratification in small eolian dunes. Sedimentology 24 361-387.

Kearsey, T., Twitchett, R.J., Newell, A.J., 2011. Origin and pedogenic significance of pedogenic dolomitic from the South Urals of Russia. Geol. Mag. 149, 291-307.

Kidder, D.L., Worsley, T.R., 2004. Causes and consequences of extreme Permo-Triassic warming to globally equable climate and relation to the Permo-Triassic extinction and recovery. Palaeogeogr. Palaeoclimatol. Palaeoecol. 203, 207-237.

Kocurek, G., 1981. Significance of interdune deposits and bounding surfaces in eolian dune sands. Sedimentology 28, 753-780.

Kocurek, G., Nelson, J., 1986. Conditions favorable for the formation of warm-climate aeolian sand sheets. Sedimentology 33, 795-816.

Lancaster, N., Teller, J.T., 1988. Interdune deposits of the Namib Sand Sea. Sediment. Geol. $55,91-107$

Linol, B., Bercovici, A., Bourquin, S., Díez, J.B., López-Gómez, J., Broutin, J., Durand, M., Villanueva-Amadoz, U., 2009. Palaeogeographical reconstructions of Upper Permian to Middle Triassic of south-western European basins: new sedimentological data from Minorca Balearic Islands, Spain. Sediment. Geol. 220, 77-94.

Loope, D.B., 1988. Rhizoliths and ancient aeolianites. Sediment. Geol. 56, 301-314.

López-Blanco, M.M., Marzo, M., Burbank, D.W., Vergés, J., Roca, E., Anadón, P., Piña, J., 2000. Tectonic and climatic controls on the development of foreland fan deltas: Montserrat and Sant Llorenc del Münt system (Middle Eocene, Ebro Basin, NE Spain). Sediment. Geol. 138, 17-39.

López-Gómez, J., Arche, A., Pérez-López, A., 2002. Permian and Triassic. In: Gibbons, W., Moreno, T. (Eds.), The Geology of Spain. Geololical Society of London Special Publication, pp. 185-212.

López-Gómez, J., Arche, A., Marzo, M., Durand, M., 2005. Stratigraphical and palaeogeographical significance of the continental sedimentary transition across the Permian-Triassic boundary in Iberia. Palaeogeogr. Palaeoclimatol. Palaeoecol. 229, $3-23$.

López-Gómez, J., Galán-Abellán, B., De la Horra, R., Barrenechea, J.F., Arche, A., Bourquin, S., Marzo, M., Durand, M., 2012. Sedimentary evolution of the continental EarlyMiddle Triassic Cañizar Formation (Central-Spain): implications for live recovery after the Permian-Triassic crisis. Sediment. Geol. 249-250, 26-44.

Mader, D., 1981. Genesis of the Buntsandstein (Lower Triassic) in western Eifel (Germany). Sediment. Geol. 29, 1-30.

Martin, E.E., Macdougall, J.D., 1995. Sr and Nd isotopes at the Permian/Triassic boundary: a record of climate change. Chem. Geol. 125, 73-99.

Marzo, M., 1980. El Buntsandstein de los Catalánides: Estratigrafía y procesos de sedimentación. Ph.D. Thesis. Barcelona University. Unpublished.

Marzo, M., 1986. Secuencias fluvio-eólicas en el Buntsandstein del Macizo de Garraf (provincia de Barcelona). Cuad. Geol. Iber. 10, 207-233.

Marzo, M., Anadón, P., 1977. Evolución y características sedimentológicas de las facies fluviales basales del Buntsandstein de Olesa de Montserrat (provincia de Barcelona). Cuad. Geol. Iber. 4, 211-222.

Marzo, M., Calvet, F., 1985. Guía al Triásico de los Catalánides. Institut d'Estudis Ilerdencs (Field Guide, 175 pp.)

McKie, T, 2011. Architecture and behavior of dryland fluvial reservoirs, Triassic Skagerrak Formation, Central North Sea. In: Davidson, S.K., Leleu, S. (Eds.), From River to Rock Record: The Preservation of Fluvial Sedimentation and Their Subsequent Interpretation. SEPM Spec. Publ., 97, pp. 189-214.

McKie, T., Williams, B., 2009. Triassic palaeogeography and fluvial dispersal across the northwest European Basins. Geol. J. 44, 711-741.

McKie, T., Shannon, P.M., 2011. Comment on "the Permian-Triassic transition and the onset of Mesozoic sedimentation at the northwestern peri Tethyan domain scale: palaeogeographic maps and geodynamic implications. Palaeogeogr. Palaeoclimatol. Palaeoecol. 311 (1-2), 136-143.

Bourquin, S., Bercovici, A., López-Gómez J. Díez J.B., Broutin, J, Ronchi, A, Durand, M. Arche, A Linol, B., Amour, F, 2011. Palaeogeogr. Palaeoclimatol. Palaeoecol. 299, 265-280.

Miall, A.D., 1978. Lithofacies types and vertical profile models in braided river deposits: a summary. In: Miall, A.D. (Ed.), Fluvial Sedimentology. Can. Soc. Petrol. Geol. Mem., 5 , pp. 590-604.

Miall, A.D., 1992. Alluvial deposits. In: Walker, R.G., James, N.P. (Eds.), Facies Models: Response to Sea Level Change. Geological Association of Canada, St. John's, Newfounland, pp. 119-142. 
Miall, A.D., 1996. The Geology of Fluvial Deposits. Sedimentary Facies, Basin Análisis and Petroleum Geology. Springer-Verlag, Berlin (582 pp.).

Mountney, N.P., 2006. Eolian facies models. In: Posamentier, H.W., Walker, R.G. (Eds.), Facies Models Revisited. SEPM Spec. Publ., 84, pp. 19-83.

Mountney, N.P., 2012. A stratigraphic model to account for complexity in aeolian dune and interdune successions. Sedimentology 59, 964-989.

Mountney, N.P., Thompson, D.B., 2002. Stratigraphic evolution and preservation of aeolian dune and dam/wet interdune strata: an example from the Triassic Helsby Sandstone Formation, Cheshire Basin, UK. Sedimentology 49, 805-834.

Pavelic, D., Kovacic, M., Vlahovic, I., Wacha, L., 2011. Pleistocene calcareous aeolianalluvial deposition in a steep relief karstic coastal belt (island of Hvar, eastern Adriatic, Croatia). Sediment. Geol. 230, 64-79.

Payne, J.L., Krump, L.R., 2007. Evidence for recurrent Early Triassic massive volcanism from quantitative interpretation of carbon isotope fluctuations. Earth Planet. Sci. Lett. 256, 264-277.

Payne, J.L., Lehrmann, D.J., Wei, J., Orchard, M.J., Scharg, D.P., Knoll, A.H., 2004. Large perturbations of the carbon cycle during recovery from the end-Permian extinction. Science 305, 506-509.

Péron, S., Bourquin, S., Fluteau, F., Guillocheau, F., 2005. Paleoenvironment reconstruction and climate simulations of the Early Triassic: impact of the water and sediment supply on the preservation of fluvial system. Geodin. Acta 18 (6), 431-446.

Preto, N., Kustatscher, E., Wignall, P.B., 2010. Triassic climates - State of the art and perspectives. Palaeogeogr. Palaeoclimatol. Palaeoecol. 290, 1-10.

Pruss, S.B., Bottjer, D.J., 2005. The reorganization of reefs communities following the endPermian mass extinction. C. R. Palevol 4, 553-568.

Pruss, S., Corsetti, F., Bottjer, D.J., 2005. The unusual sedimentary rock record of the Early Triassic: a case study from the southwestern United States. Palaeogeogr. Palaeoclimatol. Palaeoecol. 222, 33-52.

Ramos, A., Sopeña, A., 1993. Gravel bars in low-sinuosity streams (Permian and Triassic, central Spain). In: Collinson, J.D., Lewin, J. (Eds.), Modern and Ancient Fluvial Systems. IAS Spec. Publ., 6, pp. 301-312.

Retallack, G.J., Sheldon, N.D., Carr, P.F., Fanning, M., Thompson, C.A., Williams, M.L., Jones, B.G., Hutton, A., 2011. Multiple Early Triassic greenhouse crises impeded recovery from Late Permian mass extinction. Palaeogeogr. Palaeoclimatol. Palaeoecol. 308, 233-251.

Rice, S.P., Church, M., Woolridge, C.L., 2009. Morphology and evolution of bars in a wandering gravel-bed river; lower Fraser river, British Columbia, Canada. Sedimentology 56, 709-736

Roca, E., Sans, M., Cabrera, L.L., Marzo, M., 1999. Modelo tectosedimentario del sector central y septentrional del margen catalán sumergido (cubetas de Barcelona, Sant Feliu, Begur y Riumors-Roses) Libro Homenaje a José Ramírez del Pozo. AGGEP, Madrid 99-217.

Rodríguez-López J.P. Meléndez, N., de Boer, P.L, Soria, A.R.,2010. The action of wind and water in a mid-Cretaceous subtropical erg-margin system close to the Variscan Iberian Massif, Spain. Sedimentology 57 (6), 1315-1356.

Rodríguez-López, J.P., Meléndez, N., de Boer, P.L., Soria, A.R., 2011. Control son marine erg-margin cycle variability: aeolian-marine interaction in the mid-Cretaceous Iberian Desert System, Spain. Sedimentology 59 (2), 466-501.

Rodríguez-López, J.P., Liesa, C., van Dam, J., Lafuente, P., Arlegui, L., Ezquerro, L., de Boer, P., 2012. Aeolian construction and alluvial dismantling of a fault-bounded intracontinental aeolian dune field (Teruel Basin, Spain): a continental perspective on Late Pliocene climate change and variability. Sedimentology 59, 1536-1567.

Röhling, H.G., 1991. A lithostratigraphic subdivisión of the Lower Triassic in the Northwest German Lowlands and the German sector of the North Sea, based on gammaray and sonic logs. Geol. Jahrb. 119, 3-24.

Romano, C., Goudemand, N., Vennemann, T.W., Ware, D., Schneebeli-Hermann, E., Houchuli, P.A., Brühwiler, T., Brinkmann, W., Bucher, H., 2013. Climatic and biotic upheavals following the end-Permian mass extinction. Nat. Geosci. 6, 57-60.

Ronchi, A., Arche, A., Durand, M., López-Gómez, J., 1988. Linking Sardinia to stable Europe in Permian-Middle Triassic times: stratigraphic correlation and paleogeographic scenario in the Western Peri-Tethian Domain. In: Pascucci, V. Andreucci, S. (Eds.), abstract Book 27th IAS Meeting of Sedimentology, Alguero, September, 2009, 20-23. Elsevier, Amsterdam, p. 332.

Ronchi, A., Arche, A., Cassinis, G., López-Gómez, J., Spadaccini, S., 2008a. Correlation between Permian-Middle Triassic continental sequences in Western Mediterranean are (SE Iberian Range, Sardinia and Provence). Rend. Online Soc. Geol. Ital. 3, 687-688.

Ronchi, A., Sarria, E., Broutin, J., 2008b. The "Autuniano Sardo": basic features for a correlation through the Western Mediterranean and Paleoeurope. Boll. Soc. Geol. Ital. 127 (3), 655-681.

Sánchez-Martínez, S., De la Horra, R., Arenas, R., Gerdes, A., Galán-Abellán, B., LópezGómez, J., Barrenechea, J., Arche, A., 2012. U-Pb ages of detrital zircons from the
Permo-Triassic series of the Iberian Ranges: a record of variable provenance during rift propagation. J. Geol. 120, 135-154.

Schneebeli-Hermann, E., 2012. Extinguishing a Permian world. Geology 40 (3), 287-288

Sellwood, B.W., Valdes, P.J., 2007. Mesozoic climates. In: Haywood, W.M., Gregory, A.M. Schmidt, D.N. (Eds.), Deep-Time Perspectives on Climate Change: Marrying the Signal from Computer Models and Biological Proxies. The Micropalaeontological Society Special Publication. The Geological Society of London, pp. 201-224.

Shen, J., Algeo, T.J., Hu, Q., Zhang, N., Zhou, L., Wenchen, X., Shucheng, X., Feng, O., 2012 Negative C-isotope excursions at the Permian-Triassic boundary linked to volcanism. Geology 40 (11), 963-966.

Smith, R.M.H., 1995. Changing fluvial environments across the Permian-Triassic boundary in the Karoo Basin, South Africa, and possible causes of tetrapods extinction. Palaeogeogr. Palaeoclimatol. Palaeoecol. 117, 81-104.

Smith, N.D., Clough, S.R., Cross, T.A., Duffic, J.P., 1989. Anatomy of an avulsion. Sedimentology $36,1-23$.

Solé de Porta, N., Calvet, F., Torrento, L., 1987. Análisis palinológico del Triásico de los Catalánides. Cuad. Geol. Iber. 11, 237-254.

Song, H., Wignall, P.B., Tong, J., Yin, H., 2013. Two pulses of extinction during the PermianTriassic crisis. Nat. Geosci. 6, 52-56.

Soria, A.R., Liesa, C., Rodriguez-López, J.P., Meléndez, N., De Boer, P., Meléndez, A., 2011. An Early Triassic evolving erg system (Iberian Chain, NE Spain): paleoclimate implications. Terra Nova 23, 76-84.

Spalletti, L.A., Limarino, C.O., Colombo, F., 2010. Internal anatomy of an erg sequence from aeolian-fluvial system of the De La Cuesta Formation (Paganzo Basin, northwestern Argentina). Geol. Acta 8 (4), 431-447.

Stampfli, G.M., Borel, G.D., 2002. A plate tectonic model for the Paleozoic and Mesozoic constrained by dynamic plate boundaries and restored synthetic oceanic isochrones. Earth Planet. Sci. Lett. 196, 17-33.

Stanistreet, I.G., Stollhofen, H., 2002. Hoanib River flood deposits of Namib Desert interdunes as analogues for thin permeability barrier mudstone layers in aeolianite reservoirs. Sedimentology 49, 719-736.

Stolfová, K., Shannon, P.M., 2009. Permo-Triassic development from Ireland to Norway: basin architecture and regional controls. Geol. J. 44, 652-676.

Sun, Y., Joachimski, M.M., Wignall, P.B., Yan, C., Chen, Y., Jiang, H., Wang, L., Lai, W., 2012. Lethally hot temperatures during the Early Triassic greenhouse. Science 338, 366-370.

Swiecicki, T., Wilcockson, P., Canham, A., Whelan, G., Homann, H., 1995. Dating, correlation and stratigraphy of Triassic sediments in the West Shetlands area. In: Boldy, S.A.R. (Ed.), Permian and Triassic Rifting in Northwest Europe Geological Society Special Publication 91, pp. 57-85.

Szurlies, M., 2007. Latest Permian to Middle Triassic cyclo-magnetostratigraphy from the Central European Basin, Germany: implications for the geomagnetic polarity timescale. Earth Planet. Sci. Lett. 261, 602-619.

Tripaldi, A., Limarino, C.O., 2008. Ambientes de interacción eólica-fluvial en valles intermontanos: ejemplos actuales y antiguos. Lat. Am. J. Sedimentol. Basin Anal. 15, 43-66.

Twitchett, R.J., 1999. Palaeoenvironments and faunal recovery after the end-Permian mass extinction. Palaeogeogr. Palaeoclimatol. Palaeoecol. 154, 27-37.

Tyrrell, S., Haughton, P.B.W., Souders, A.K., Daly, J.S., Shanonn, P.M., 2012. Large-scale, linked drainage systems in the NW European Triassic. Insights from the Pb isotopic composition of detrital K-feldspar. J. Geol. Soc. Lond. 169, 279-295.

Ubide, T., Lago, M., Arranz, E., Gale, C., Larrea, P., 2010. The lamprophyric sub-vertical dyke swarm from Aiguablava (Catalonian Coastal Ranges): petrology and composition. Geogaceta 49, 83-86.

Ulicný, D., 2004. A drying-upward aeolian system of the Bohdasín Formation (Early Triassic), Sudetes of NE Czech Republic: record of seasonality and long-term palaeoclimate change. Sediment. Geol. 167, 17-39.

Vargas, H., Gaspar-Escribano, J., López-Gómez, J., van Wees, J.-D., Cloetingh, S., De la Horra, R., Arche, A., 2009. A comparison of the Iberian and Ebro Basins during the Permian and Triassic, eastern Spain: a quantitative subsidence modelling approach. Tectonophysics 474, 160-183.

Vermeesch, P., Fenton, C.R., Kober, F., Wiggs, G.F.S., Bristow, C.S., Xu, S., 2010. Sand residence times of one million years in the Namib Sand Sea from cosmogenic nuclides. Nat. Geosci. 3 (12), 862-865.

Virgili, C., 1958. El Triásico de los Catalanides. Bol. Inst. Geol. Min. Esp. 69 (856 pp.).

Woods, A.D., 2005. Paleoceanographic and paleoclimatic context of Early Triassic time. C. R. Palevol 4, 463-472.

Xie, S., Pancost, R., Wang, Y., Yang, H., Wignall, P., Luo, G., Jia, Ch., Chen, L., 2010. Cyanobacterial blooms tied to volcanism during the 5 m.y. Permo-Triassic biotic crisis. Geology 38, 447-450.

Ziegler, P.A., 1988. Post-Hercynian plate reorganization in the Tethys and Artic-North Atlantic domains. In: Manpeizer, W. (Ed.), Triassic-Jurassic Rifting. Dev. Geotectonics, 22. Elsevier, Amsterdam, pp. 711-755. 